\title{
Cell Regulation of Proliferation and Differentiation ex vivo for Cells Containing Ph Chromosome in Chronic Myeloid Leukemia
}

\author{
N.I. Grineva*, T.V. Akhlynina, L.P. Gerasimova, T.E. Manakova, N.G. Sarycheva, D. A.Schmarov, \\ A.M. Tumofeev, N.M. Nydenova, L.Yu. Kolosova, T.I. Kolosheynova, L.G. Kovaleva, \\ S.V. Kuznetsov, A.V. Vorontsova, A.G. Turkina \\ GU National Research Center for Hematology, Russian Academy of Medical Sciences \\ *E-mail: nigrin27@mail.ru
}

\begin{abstract}
Cell regulation of $\mathrm{Ph}^{+}$cell proliferation and differentiation has been studied ex vivo in various chronic myeloid leukemia (CML) patients. The regulation is provided by alternation of effective stages of proliferation and maturation with inhibition of $\mathrm{Ph}^{+}$cell proliferation by accumulating neutrophils under apoptosis blockage. The alternation of stages consists of switching stage 1 (effective proliferation) to stage 2 (effective maturation) and proceeds according to the $1 / 2-1 / 2 / 1$ or $2 / 1-2 / 1 / 2 / 1$ schemes. The kinetic plots of alternations pass through control points of crossing plots, where the parameters of proliferation and maturation are equal. The indices of $\mathrm{P} / \mathrm{D}$ efficiency (ratio of proliferation and maturation rates) are $1.06 \pm 0.23$ and don't depend on time, alternation order, or sources of Ph ${ }^{+}$cells - CML patients. During stages alternation, conversely, the parameters of Ph+ cell proliferation and maturation vary. The proliferation stages are characterized by increased proliferating cells content, a decreased number of neutrophils, and apoptosis induction. At the maturation stages, conversely, apoptosis is inhibited, the number of mature neutrophils increases, while immature $\mathrm{Ph}^{+}$cells decrease. High content neutrophils inhibit the proliferation of $\mathrm{Ph}^{+}$cells and impair their own maturation by inversion of maturation order, probably through a feedback mechanism. The regulation differences ex vivo reveal three types of $\mathrm{Ph}^{+}$cells from various individual CML patients, distinguished by the number and duration of alternating stages of proliferation and maturation. $\mathrm{Ph}{ }^{+}$cells types 1 and 2 have one prolonged stage of effective proliferation or effective maturation with efficiency indices $\mathrm{P} / \mathrm{D}^{1}=1-20$ or $\mathrm{P} / \mathrm{D}^{2} \leq 1$. At the same time period, the proliferation and differentiation of the $\mathrm{Ph}^{+}$cells type 3 proceeds with repeated alternations of stages with $\mathrm{P} / \mathrm{D}^{1}=1-4$ or $\mathrm{P} / \mathrm{D}^{2} \leq 1$. Type $1 \mathrm{Ph}^{+}$cells $(\sim 20 \%)$ were isolated from patients in advanced stages of CML, while $\mathrm{Ph}^{+}$cells types 2 and 3 (30 and 50\% correspondingly) were isolated from CML chronic phase patients sensitive to chemotherapy. Keywords: Regulation of $\mathrm{Ph}^{+}$cell proliferation and $\mathrm{Ph}^{+}$cell by mature cells, cultivation of hematopoietic $\mathrm{Ph}^{+}$mononuclear cells, kinetics of $\mathrm{Ph}^{+}$cell proliferation and differentiation in vitro, $\mathrm{Ph}^{+}$cells apoptosis, $\mathrm{Ph}^{+}$cell distribution in cell cycle phases, $\mathrm{Ph}^{+}$cell proliferation and differentiation efficacy, inversion of accumulation order for maturating neutrophils, chronic myeloid leukemia.

Abbreviations: P\&D - proliferation and differentiation; CML - chronic myeloid leukemia; Ph - Philadelphia chromosome; MM, B, S, - metamyelocytes, band and segmented neutrophils; $\mathrm{Ph}^{+}$cells - hematopoietic cells with Philadelphia chromosome; $\mathrm{PB}$ - peripheral blood ; $\mathrm{BM}$ - bone marrow; CP, AP, BP - chronic phase, accelerated phase and blastic phase of CML; FCS - fetal calf serum.
\end{abstract}

\section{INTRODUCTION}

Leukemias accounts for $1 \%$ of all deaths and $4-10 \%$ of deaths from cancer. The prevalence of leukemias and lymphomas varies from 3 to $9: 100000$, depending on the geographical region. Unfavorable radiation and ecological environment can increase it by 1.5 logs. In the U.S., leukemias are the major reason of death in children before 15 .

The majority of leukemias result from genetic disturbances: chromosomal aberrations, translocations, inversions, deletions, and various mutations $[1-3,6]$.

Philadelphia-positive $\left(\mathrm{Ph}^{+}\right)$cells, expressing active tyrosine kinase p210 or p185 (oncoproteins, products of bcr/ abl gene), are involved in chronic myeloid leukemia (CML) pathogenesis. It results in reciprocal chromosomal translocation $t(9 ; 22)(q 34 ; q 11)$ in the polipotent hematopoietic stem cell. Proliferation and differentiation of this cell leads to replacement of normal hematopoietic cells by their monoclonal neoplastic $\mathrm{Ph}^{+}$counterparts, thus promoting the development and progress of CML $[1-8,10,12]$.

The CML clinical course varies among different patients. The cellular and molecular mechanisms of these differences remain unclear. Current knowledge of CML course and progression in vivo is based upon analyses of averaged values of various parameters obtained at different moments and CML phases. CML undergoes a chronic phase (CP), accelerated phase (AP), and an acute rapidly progressing blast phase (BP) with an inevitable fatal outcome. Current CML therapy is based upon highly specific targeted drugs, tyrosine kinase inhibitors (TKI), specifically blocking p210 - imatinib and its analogues. Imatinib allows to extend life by 6 years in $88 \%$ of patients., of which $66 \%$ continue treatment. In $14 \%$ of those patients, CML progresses, while $5 \%$ of them interrupt treatment because of toxicity. The toxicity is associated with additional bcr/abl gene mutations, leading to therapeutic resistance. Despite the development of a new generation of TKIs, the problem remains unsolved, because none of them kills the resting leukemia stem cells. Fewer than $5 \%$ of CML chronic phase patients are cured, while the majority eventually relapse [6]. There is a need for another strategy in dealing with leukemia stem cells.

Despite the extensive research of $\mathrm{Ph}^{+}$cells both in cultures and in vivo [4, 5, 7-12, 15-20,23,27], the processes taking place 
in the cells of newly diagnosed CML patients and in those in progression remain poorly studied. There is no unified conception of the biological and molecular processes underway in CML both in vitro and in vivo and their interaction. Little is known about the patterns of proliferation and differentiation $(\mathrm{P} \& \mathrm{D})$ of $\mathrm{Ph}^{+}$cells even in vitro.

Researchers have often noted that the cellular processes in cells isolated from CML patients differ from those in cell lines. The number of proliferating hematopoietic progenitors in CML is decreased, while the number of nondividing mature neutrophils is higher than in normal cells [13,14,20$23,26] . \mathrm{Ph}^{+}$stem cells proliferate less actively than healthy donor stem cells, while more differentiated $\mathrm{Ph}^{+}$cells are accumulating more actively [20, 23, 24, 27]. This leads to suggest that the cause of CML is the imbalance between stem cells self-renewal and myeloid progenitors maturation, rather than $\mathrm{Ph}^{+}$cells proliferation under the action of $\mathrm{p} 210$ bcr/abl, as follows from many other studies [4-7,10-12, 15, 16, 19, 24-29, 31].

It should be mentioned that the question of apoptosis block in $\mathrm{Ph}^{+}$cells is also not obvious. Evidently, our knowledge of cellular and molecular regulation of $\mathrm{Ph}^{+}$cells in CML is still incomplete, though the oncogenic potential of bcr/abl oncogene, including enhanced cell viability, proliferation activation, and resistance to apoptosis, is studied in details in various studies [7, 4,17,18, 25-27, 29, 30, $35,43-45]$.

The influence of different p210 mutations on proliferation, apoptosis, and the malignant properties of $\mathrm{Ph}^{+}$cells transfected with different bcr/abl mutated variants was studied in [27]. The activation of proliferation and apoptosis inhibition by 210 was shown to be independent processes closely linked to different bcr/abl mutations (including those responsible for intracellular signaling via various STAT proteins). It was hypothesized that those mutations can influence the severity of proliferation activation and apoptosis inhibition and shift their relative impact. In $\mathrm{Ph}^{+}$cells of CML patients, these properties are not studied due to lack of suitable models and experimental approaches, though the bcr/abl mutations are actively studied and used in practice for CML diagnosis and treatment optimization [19, 29, 30-32]. Based on these considerations, we have suggested that the kinetics of $\mathrm{Ph}^{+}$cells $\mathrm{P} \& \mathrm{D}$ can reveal the differences in $\mathrm{Ph}^{+}$cells $\mathrm{P} \& \mathrm{D}$ regulation of individual patients ex vivo.

The goal of our study was to clarify the mechanism of $\mathrm{Ph}^{+}$cells $\mathrm{P} \& \mathrm{D}$ in individual CML patients ex vivo in suspension cultures by means of the previously developed kinetic method of study $[33,39]$. The pattern of CML cells proliferation and differentiation in cultures is similar to that of enhanced myelopoiesis in CML in vivo, allowing to estimate the efficiency of $\mathrm{P} \& \mathrm{D}$, influence of growth factors, and the expression of bcr/abl and differentiation antigens in $\mathrm{Ph}^{+}$ cells.

\section{MATERIALS AND METHODS}

Materials: heparin (Flow, UK); Limphoprep, alpha-MEM media (MP Biomedical, USA); DEPC, Hepes, Tris, PBS, fetal bovine serum (FBS), sodium citrate, laurilsarcosyl (ICN, USA); trypan blue stain, L-glutamine and 2-mercaptoethanol (Serva, Germany), penicillin and streptomycin (OAO "Biochimik" Saransk Russia); G-CSF (F.Hoffmann-La Roche Ltd, France); tabletted PBS (10 mM phosphate buffer+0,13 $\mathrm{M} \mathrm{NaCl}+2,7$ mM KCl, pH 7,4), NPZ "EKO-servise" Russia.

$\mathrm{Ph}^{+}$mononuclear cells used for the study were prepared from the peripheral blood (PB) or bone marrow (BM) of CML patients in chronic phase (CP), accelerated phase (AP), and blastic phase (BP) before or under treatment. Leucocytes and granulocytes are the main CML mononuclears content; namely, they have been investigated here. Characteristics of $\mathrm{Ph}+$ cells and CML patients from whose $\mathrm{PB}$ and $\mathrm{BM}$ the mononuclears were isolated are given in Tables 1-3. In $\mathrm{Ph}+$ cells, bcr/abl RNA types as b3a2, b2a2, or e1a2 were assayed by $\mathrm{RT}-\mathrm{PCR}$ (reverse transcription-polymerase chain reaction) according to [33, 35].

$\mathrm{Ph}^{+}$mononuclear cells were isolated from $10-15 \mathrm{ml}$ of $\mathrm{PB}$ or 1-2 $\mathrm{ml}$ of BM aspirate (from superior iliac crest) of CML patients at different phases of the disease. The heparinized (50 IU/ml) material was centrifuged for $30 \mathrm{~min}$ at $1500 \mathrm{rpm}$ over Phycoll or Lymphoprep (1.077 or $1.119 \mathrm{~g} / \mathrm{sm}^{3}$ ). The resulted light fraction was washed twice with PBS at $\mathrm{pH} 6.8$ and once with a $\alpha$-MEM media and then re-suspended in $\alpha-\mathrm{MEM}$ media for analysis and cell cultivation. This fraction contained progenitor cells (blasts), lymphocytes, granulocytes, and monocytes, as well as some quantities of mature neutrophils, typical for CML mononuclear cells. The viable and dead cell number was counted 3 times in smears, stained by $0.2 \%$ trypan blue according to Romanovsky, with consequent cell counting in Goryaev's chamber.

$\mathrm{Ph}^{+}$cells cultivation was performed according to [33]. Cell suspension of $2 \div 8 \cdot 10^{6}$ cells $/ \mathrm{ml}$ was incubated with $\alpha$-MEM media containing 10-20\% fetal calf serum (FCS, $2 \mathrm{mM}$ Lglutamine, $10^{-4} \mathrm{M}$ 2-mercaptoethanol, $100 \mathrm{U} / \mathrm{ml}$ penicillin and $50 \mathrm{U} / \mathrm{ml}$ streptomycin, $25 \mathrm{mM}$ HEPES-NaOH, pH 7.2-7.4 in $25 \mathrm{sm}^{2}$ plastic flask for $2-3 \mathrm{~h}$ ) nonadherent cells were then centrifuged at $1500 \mathrm{rpm}$ for $7 \mathrm{~min}$ and re-suspended with the same medium to $0.8 \div 1.4 \cdot 10^{6}$ cells $/ \mathrm{ml}$ and transferred to 24 or 96 -well plates (12 wells per probe) and incubated at $37{ }^{\circ} \mathrm{C}$ with $100 \%$ humidity and 5\% CO2 without FCS for $2 \mathrm{~h}$. Then $10-20 \%$ of FCS was added, and the cells were cultured for 6-14 days, selecting each sample from separate probes. Every point was tested in triplex. $\mathrm{Ph}^{+}$cells in the collected samples were washed from FCS by centrifuging in $\alpha$-MEM media and analyzed for their morphology, cellular composition, distribution in the cell cycle phases, and apoptosis. We had separately determined that 2-hour incubation of cells without FCS with consequent incubation with FCS diminishes cell proliferation during the next $\sim 6$ hours. After that, the proliferation rate is restored, and 12 hours later the cellular composition becomes the same as in the cultures with FCS.

The prepared probes were analyzed for the number of viable and dead cells and cell morphology in 3 zones of smear (100 cells in each) according to Romanovsky, the individual cell morphology was identified according to Abramov [34], and we also calculated the percentage of each cell type in every sample. We calculated cell concentration in samples in $10^{6}$ cells $/ \mathrm{ml}$ and obtained plots for the kinetic curves of accumulation and depletion of different $\mathrm{Ph}^{+}$cells and their subpopulations: proliferating cells (blasts, promyelocytes and myelocytes) - $\mathrm{P}$ and nondividing mature neutrophils: MM, B and S (metamyelocytes, band and segmented neutrophils) - D. The plots reflected the rate of production (or 
accumulation) of each differentiating cell type, transforming to the next subpopulation for this cell differentiation line. The mean error was $\pm 5 \div 11 \%$. We also studied apoptosis and cell cycle phase distribution by flow cytometry.

$\mathrm{Ph}$-chromosome in $\mathrm{PB}$ and BM cells of our patients was identified cytogenetically (for 100 mitoses) or by FISH in the cytogenetical laboratory of the National Research Center for Hematology.

Flow cytometry for the analysis of the cell cycle phase distribution of the cultured $\mathrm{Ph}^{+}$cells selected during the incubation of $\mathrm{Ph}^{+}$cells samples (5,000 cells each) after the isolation in Phycoll gradient were centrifuged for $7 \mathrm{~min}$ at $2000 \mathrm{rpm}$ and $4^{\circ} \mathrm{C}$, washed with PBS, and accurately fixed by cold $70 \%$ ethanol for $30 \mathrm{~min}$ at $4^{\circ} \mathrm{C}$. Before measurement, the suspension was washed with PBS, centrifuged, and the pellet was incubated in $0.5 \mathrm{ml}$ of PBS containing $5 \mathrm{mcg} / \mathrm{ml}$ of propidium iodide and $50 \mathrm{mcg} / \mathrm{ml}$ of ribonuclease A for 30 min at room temperature in a dark place [36, 37]. The cell measurements were done with flow cytometer EPICS-XL. Cells of granulocytes gate were analyzed by direct (FSC) and side (SSC) light scatter with simultaneous registration of the FL2 fluorescence by amplitude and impulse square (it allows to exclude aggregated cells, conglomerates, and debris) in the linear and logarithmic scales. Simultaneously apoptotic cells are detected. FL2-H particles with hypodiploid DNA located as a separate peak leftward of the peak of diploid cells (decrease of cell size not more than by 2 logs) were considered to be apoptotic. The percentage of apoptotic granulocytes was estimated within the granulocytic gate, where there is no cell debris. The DNA histograms from the same cell samples were analyzed for cell cycle phase distribution (S, G2/M). Its analysis was done with the help of previously developed specialized software. It was based upon an algorithm developed for asynchronous proliferating cell populations (SFIT-method) [38].

The kinetic plots of $\mathrm{Ph}^{+}$leucocytes (number increase and death of $\mathrm{Ph}^{+}$cells) were obtained using the percentage of viable and dead cells (see above) measured in $10^{6}$ cells $/ \mathrm{ml}$. The proliferation rate of leucocytes in whole and granulocytes in particular was estimated from the kinetic plots of its accumulation and depletion under cultivation and also from the sum of its subpopulations, defined by morphology. The kinetic curves showed that the accumulation and consumption of each studied type of cells parallels its transformation into the next subpopulations. The depletion of segmented neutrophils means its death.

Differentiation plots of $\mathrm{Ph}^{+}$leucocytes and its subpopulations - lymphocytes, all myeloid cells, granulocytes, and its subpopulations, blasts, promyelocytes, myelocytes, metamyelocytes, band and segmented neutrophils - were defined, calculating the concentration of corresponding cells in samples and multiplying its fraction (defined by morphology in smears) by $10^{6} / \mathrm{ml}$. The cell morphology in smears was assessed as already mentioned. The cellular composition was assessed in smears in 3 zones of 100 cells each. It should be noted that besides morphology $\mathrm{Ph}^{+} \mathrm{CML}$ cells № 1.1 and № 2.6 were identified by CD antigens expression according to [39], where the results of identification and kinetics of cells according to both antigen expression and morphology are given and results are shown to be coincident [33, 39].
Kinetic plots of $\mathrm{P} / \mathrm{D}$ efficiency. $\mathrm{P} / \mathrm{D}$ of granulocytes in $\mathrm{Ph}^{+}$ cell cultures was defined as the $\mathrm{P} / \mathrm{D}$ efficiency index that is the rate ratio of accumulation and depletion of proliferating cells ( $\mathrm{P}$ cells sum) and neutrophils matured without dividing ( $\mathrm{D}$ cells sum) under $\mathrm{Ph}^{+}$mononuclear cells cultivation as defined above.

The $\mathrm{P} / \mathrm{D}$ efficiency index was defined as the ratio of $\mathrm{P}$ cells (proliferation rate) and $\mathrm{D}$ cells (differentiation rate). It is equivalent to the ratio between the concentration of these cells, according to consideration $\mathrm{V}_{\mathrm{P}} / \mathrm{V}_{\mathrm{D}}=\mathrm{K}_{\mathrm{P}}[\mathrm{P}] \mathrm{t} / \mathrm{K}_{\mathrm{D}}[\mathrm{D}] \mathrm{t}$ $=\mathrm{K}_{\mathrm{P}} / \mathrm{K}_{\mathrm{D}} \mathrm{x}[\mathrm{P}] /[\mathrm{D}]$, where $\mathrm{V}_{\mathrm{P}}$ and $\mathrm{V}_{\mathrm{D}}$ are the rates of $\mathrm{P}$ and $\mathrm{D}$ cells accumulation; $\mathrm{K}_{\mathrm{P}}$ and $\mathrm{K}_{\mathrm{D}}$, constants of rate; and $[\mathrm{P}]$ and [D], cell concentrations. $K_{P} / K_{D}=K$ is the constant of relative $\mathrm{P} / \mathrm{D}$ efficiency.

\section{RESULTS}

In order to study the differences in $\mathrm{P} \& \mathrm{D}$ in the $\mathrm{Ph}^{+}$cell cultures of patients with different CML phases, we obtained kinetic plots for 34 samples of $\mathrm{Ph}^{+}$mononuclear cells from the $\mathrm{PB}$ and $\mathrm{BM}$ of $23 \mathrm{CML}$ patients under cultivation in strictly identical conditions. $\mathrm{Ph}^{+}$mononuclear cells from $\mathrm{PB}$ and $\mathrm{BMI}$ contain hematopoietic cells capable of self-renewal at P\&D and to $\mathrm{P} \& \mathrm{D}$ for 2-3 cycles, forming the full set of $\mathrm{Ph}^{+}$cells $[33,39]$.

The majority of mononuclear cells in CML are leucocytes $[1,7]$; thus, we considered them as $\mathrm{Ph}^{+}$cells. The leucocytes subpopulations include granulocytes, lymphocytes, monocytes; the granulocyte subpopulation contains myeloid precursors (blasts), promyelocytes, myelocytes and mature neutrophils: metamyelocytes (MM), band (B), and segmented (S) neutrophils.

The characteristics of $\mathrm{Ph}^{+}$cells and corresponding CML patients are given in Tables 1-3. In cell samples obtained under cultivation, we obtained the kinetic plots of CML leucocytes proliferation and death and differentiation of $\mathrm{Ph}^{+}$granulocytes subpopulations: blasts, promyelocytes, myelocytes, MM, B and S. In the same samples, we also assayed plots for apoptosis and distribution of $\mathrm{Ph}^{+}$cells in the cell cycle phases (Fig. 1-4). The experiments showed a typical for CML elevated granulocytes content $[1,6,14]$. The shape of the plots indicates the rate of production or accumulation of the corresponding cell type, their transformation to next subpopulations, and final death. Thus, the resulting plots reflect the main differentiation processes (Fig.1-4 and Tables.1-3). The leucocytes differentiation coincides with known CML data [1-3, 21, 22, 40-42].

Besides the differentiation rate of separate subpopulations (Fig.1-4 a), we studied the plots of overall proliferation and maturation rate. In the $1^{\text {st }}$ case, these were the plots of accumulation of $\mathrm{P}$ cells differentiating in parallel with proliferation and including blasts - myeloid cell precursors, promyelocytes, and myelocytes. In the $2^{\text {nd }}$ case, they were the plots of accumulation of neutrophils $-D$ cells: the sum of MIM, B, and S matured without dividing (Fig.1-4 b).

\section{TYPES OF CML CELLS}

Myelopoiesis (P\&D of myeloid division of hematopoiesis) begins with the proliferation and differentiation of hematopoietic progenitor cells and their immature progenies. Then P\&D 
Table 1. Proliferation and differentiation of types 1 and $2 \mathrm{Ph}^{+}$cells in culture

\begin{tabular}{|c|c|c|c|c|c|c|c|c|c|}
\hline \multirow[b]{2}{*}{$\mathrm{N}$} & \multicolumn{3}{|c|}{$\begin{array}{l}\text { Samples of mononuclear cells from PB or BM } \\
\text { of CML patients }\end{array}$} & \multicolumn{6}{|c|}{ Proliferation and differentiation parameters } \\
\hline & $\begin{array}{c}\text { Sample } \\
\text { number } \\
\text { CML PB or } \\
\text { BM }\end{array}$ & $\begin{array}{c}\text { Diagnosis, } \\
\text { treatment } \\
\text { before } \\
\text { sampling }\end{array}$ & $\begin{array}{c}\text { Type of bcr/ } \\
\text { abl RNA, } \\
\text { leucocytes } \\
\text { x } 10^{9} / \mathrm{L} ; \\
\% \text { blasts } \\
\end{array}$ & $\begin{array}{c}\mathrm{P} / \mathrm{D}, \\
{[\text { immature]/ }} \\
{[\text { mature }]}\end{array}$ & $\begin{array}{l}\mathrm{P} / \mathrm{D} \text { dura- } \\
\text { tion, days }\end{array}$ & $\begin{array}{l}{[\mathrm{S}] /} \\
{[\mathrm{M}]}\end{array}$ & $\begin{array}{c}\mathrm{S} \times 10^{6} \text { cells } / \\
\mathrm{ml}, \\
\max / \text { at day }\end{array}$ & $\begin{array}{l}\text { Neutrophils } \\
\text { x } 10^{6} \text { cells/ } \\
\text { mlmax /at day }\end{array}$ & $\begin{array}{c}\text { Apoptosis(cell } \\
\text { death) } \\
\% \text { /at day }\end{array}$ \\
\hline 1 & 2 & 3 & 4 & 5 & 6 & 7 & 8 & 9 & 10 \\
\hline
\end{tabular}

Type $1 \mathrm{Ph}^{+}$cells, $\mathrm{P} / \mathrm{D}^{1} \geq 1$. Effective proliferation (accumulation rate of immature $\mathrm{Ph}^{+}$cells is higher than neutrophils maturation rate). Concentration [immature] $>$ [mature].

\begin{tabular}{|c|c|c|c|c|c|c|c|c|c|}
\hline 1 & $\begin{array}{l}1.1 \\
\mathrm{~PB}\end{array}$ & $\mathrm{CP}$ & $\begin{array}{c}\text { b3a } 2 \text { L } 115 \text {; } \\
3 \%\end{array}$ & $\begin{array}{l}12-4 \\
4-1\end{array}$ & 14 & $\begin{array}{c}0,14- \\
0,0-0,27\end{array}$ & 0,17 & $\begin{array}{c}0,53 / 7 \\
-0,32 \\
-0,65 / 14\end{array}$ & $\begin{array}{c}(28 / 7 \\
50 / 14)\end{array}$ \\
\hline $\begin{array}{l}2 \\
3 \\
\end{array}$ & $\begin{array}{c}1.2 \\
\mathrm{BM} \\
\mathrm{PB}\end{array}$ & $\begin{array}{l}\mathrm{CP} \\
\text { HU* }\end{array}$ & $\begin{array}{c}\text { b3a2 } \\
\text { L } 72 \\
\text { blasts } 3 \%\end{array}$ & $\begin{array}{c}1,2-1,6 \\
2,4-1\end{array}$ & $\begin{array}{l}8 \\
8\end{array}$ & $\begin{array}{c}0,41 \\
0,5\end{array}$ & $\begin{array}{c}0,2 \\
0,2 / 3\end{array}$ & $\begin{array}{c}0,67 \\
0,58 / 3\end{array}$ & $\begin{array}{c}(33 / 4 \\
30 / 9\end{array}$ \\
\hline $\begin{array}{l}4 \\
5 \\
\end{array}$ & $\begin{array}{c}1.3 \\
\text { KM } \\
\text { PB }\end{array}$ & $\begin{array}{c}\mathrm{AP} \\
\text { Chem** }\end{array}$ & $\begin{array}{c}\text { b2a } 2 \\
\text { blasts } 17 \%\end{array}$ & $\begin{array}{c}3-9 \\
1-13 \\
\end{array}$ & $>8$ & $\begin{array}{l}0,1-0,54 \\
0,1-0,31 \\
\end{array}$ & $0,13 / 8$ & $0,17 / 0-4$ & $(14 / 8)$ \\
\hline 6 & 1.4Blood & $\underset{\text { Chem }^{* *}}{\operatorname{lymphoidBP}}$ & $\begin{array}{c}\text { b2a2 } \\
\text { blasts } \\
30 \%\end{array}$ & $>20-2$ & $>6$ & 0,0 & $0 / 0-6$ & $0,4 / 6$ & $(47 / 6)$ \\
\hline 7 & $1.5 \mathrm{~PB}$ & $\begin{array}{l}\mathrm{CP} \\
\mathrm{HU}^{*}\end{array}$ & $\begin{array}{c}\text { b3a2 } \\
\text { L } 175 \\
\text { Blasts } 5 \%\end{array}$ & $1,2-2,5$ & $<8$ & $0,14-0,53$ & $0,08 / 4$ & $\begin{array}{c}0,32-0,2 \\
/ 4,8\end{array}$ & $(21 / 7)$ \\
\hline
\end{tabular}

Type $2 \mathrm{Ph}^{+}$cells, $\mathrm{P} / \mathrm{D}^{2} \leq 1$. Effective maturation ( neutrophils maturation rate is higher than accumulation rate of immature $\mathrm{Ph}^{+}$cells). Concentration [mature] $>$ [immature].

\begin{tabular}{|c|c|c|c|c|c|c|c|c|c|}
\hline 1 & $\begin{array}{l}2.1 \\
\mathrm{~PB}\end{array}$ & $\begin{array}{c}\mathrm{CP} \rightarrow \mathrm{BP} \\
\mathrm{HU}^{*}\end{array}$ & $\begin{array}{c}\text { b3a2, } \\
\text { L } 188-145, \\
2 \%\end{array}$ & $0,3-0,8$ & $>6$ & $\begin{array}{c}1,0-1,62 \\
-0.4\end{array}$ & $0,47 / 2$ & $1,2 / 2$ & $\begin{array}{c}40 / 1 \\
4 / 3 \\
55 / 6 \\
\end{array}$ \\
\hline 2 & $2.2 \mathrm{BM}$ & $\begin{array}{c}\mathrm{CP} \\
\mathrm{HU}^{*} 4 \text { days } \\
\text { leter }\end{array}$ & b3a 2 & $0,8-1,5$ & $>5$ & $0,8-0,4-1,0$ & $0,5 / 2$ & $\begin{array}{l}0,7 / 1 \\
0,6 / 5\end{array}$ & $\begin{array}{c}(4 / 1 \\
11 / 5)\end{array}$ \\
\hline 3 & $2.3 \mathrm{~PB}$ & $\mathrm{CP}$ & b3a2 & $0,4-1,0$ & $\sim 6$ & $0,4-0,8$ & $0,25 / 3$ & $0,7 / 3$ & $\begin{array}{c}(2 / 3 \\
19 / 7)\end{array}$ \\
\hline 4 & $\begin{array}{l}2.4 \\
\mathrm{~PB}\end{array}$ & $\begin{array}{l}\mathrm{CP}, 2 \text { risk } \\
\text { group, } * * *\end{array}$ & $\begin{array}{c}\text { b3a2, } \\
\text { L } 165, \\
\text { blasts } 2 \%\end{array}$ & $0,3-1,2$ & $\sim 7$ & $\begin{array}{c}0,73 / 4 \\
2,4 / 8\end{array}$ & $0,86 / 8$ & $\begin{array}{l}2,4 / 4 \\
1,3 / 8\end{array}$ & $\begin{array}{c}(2 / 4 \\
33 / 11)\end{array}$ \\
\hline 5 & $2.5 \mathrm{~PB}$ & $\mathrm{CP}$ & $\mathrm{b} 2 \mathrm{a} 2$ & $\begin{array}{c}0,1-1,1- \\
1,6\end{array}$ & $\sim 7$ & $1,4 / 5$ & $0,7 / 5$ & $1,13 / 5$ & $\begin{array}{c}(3 / 2 \\
2 / 5 \\
17 / 7)\end{array}$ \\
\hline $\begin{array}{l}6 \\
7 \\
\end{array}$ & $\begin{array}{c}\text { 2.6 PB } \\
\text { BM }\end{array}$ & $\mathrm{CP}$ & b3a 2 & $\begin{array}{l}0,2-1,0 \\
0,3-1,0\end{array}$ & $>9$ & $\begin{array}{c}8 / 6 \\
24 / 11 \\
\end{array}$ & $0,41 / 6$ & $\begin{array}{c}0,7 / 6 \\
0,1 / 11\end{array}$ & $\begin{array}{c}(2 / 6 \\
24 / 11)\end{array}$ \\
\hline
\end{tabular}

The treatment before sampling: *hydroxyurea; ** chemotherapy. *** interferon $\mathrm{CP}, \mathrm{AP}$ and BP - chronic phase, accelerated phase, and blastic phase - CML phases.

continues with neutrophils maturation without dividing [3, $40,41]$. In this study, we obtained and analyzed ex vivo P\&D kinetic plots in 34 samples of $\mathrm{Ph}^{+}$cells from the $\mathrm{PB}$ and $\mathrm{BM}$ of 23 CML patients. They demonstrated evident differences in the $\mathrm{P} \& \mathrm{D}$ of $\mathrm{Ph}^{+}$cells from individual CML patients.

The kinetic plots of proliferation and maturation reflect the rate of two crucial $\mathrm{P} \& \mathrm{D}$ processes: proliferation with differentiation and differentiation without dividing (maturation of neutrophils). The rate ratio of proliferation (P cells ac- cumulation) and maturation (D cells) reflects the efficiency of $\mathrm{Ph}^{+}$cells proliferation relative to its maturation without dividing and is expressed in the $\mathrm{P} / \mathrm{D}$ index, an indicator of $\mathrm{P} / \mathrm{D}$ efficiency. One can see from the kinetic $\mathrm{P}$ and $\mathrm{D}$ cell plots that the proliferation rate can be higher or lower than that of maturation; thus, $\mathrm{P} \& \mathrm{D}$ can give advantage to proliferation (effective proliferation) or to maturation (effective maturation). In the first case, the $\mathrm{P} / \mathrm{D}$ efficiency index $\mathrm{P} / \mathrm{D}^{1} \geq 1$; in the second, $\mathrm{P} / \mathrm{D}^{2} \leq 1$ (Fig.1-4C, Tables 1-3). 

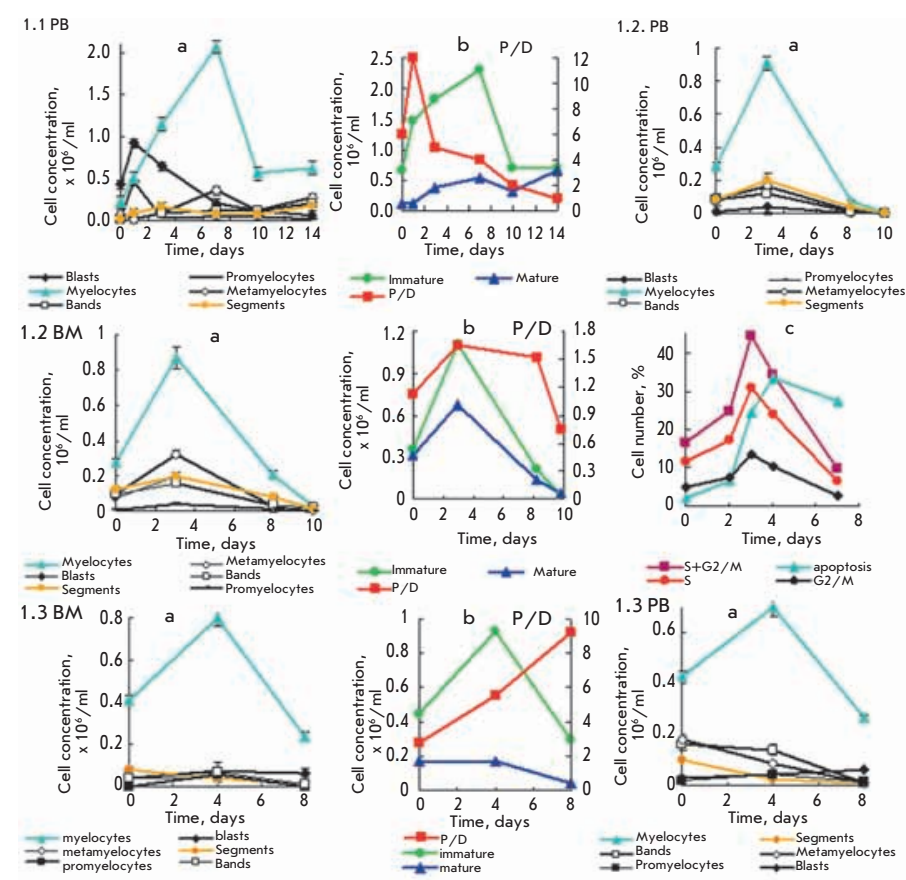
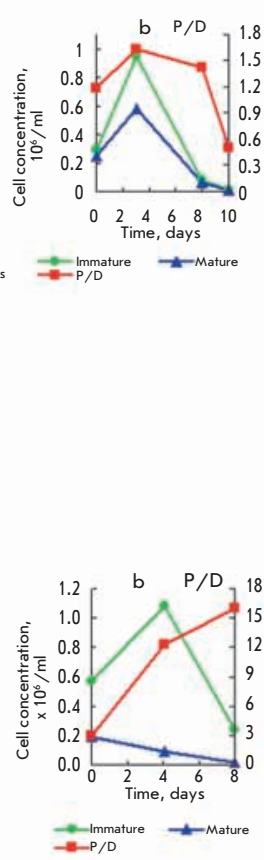

Fig. 1. Kinetics plots of proliferation and differentiation (as accumulating and consuming) of type $1 \mathrm{Ph}^{+}$cells subpopulations in the suspension culture of mononuclear cells isolated from bone marrow $(B M)$ or peripheral blood (PB) of chronic myeloid leukemia (CML) patients a - differentiation of granulocytes subpopulations with formation of proliferating myeloid precursor cells (blasts), promyelocytes, myelocytes, and neutrophils maturated without dividing: metamyelocytes, bands, and segmented; $b$ - accumulation and consumption of immature proliferating cells, $\mathrm{P}$ cells, and neutrophiles matured without dividing, $D$ cells, as well plots of proliferation and maturation efficiency as ratio of $P$ and $D$ cells accumulation rates - $P$ /D index; $c$ - plots of apoptosis and $\mathrm{Ph}^{+}$granulocyte distribution in the cell cycle phases in culture. 1.1 $\mathrm{PB}-\mathrm{PB} \mathrm{Ph}^{+}$cells from

CML CP patient \#1.1 before treatment, showing fast progression to CML BP. 1.2 PB and 1.2 $\mathrm{BM}-\mathrm{Ph}^{+}$cells from CML CP patient \#1.2; 1.3 $\mathrm{BM}$ and $1.3 \mathrm{~PB}-\mathrm{Ph}^{+}$cells isolated from patient with CML AP under treatment (rapid progression to blastic phase). Samples characteristics, as well as proliferation and differentiation data of type $1 \mathrm{Ph}^{+}$cell, are shown in Table 1
In $20 \%$ of CML patients, P\&D is associated with continuous effective proliferation only. These are type $1 \mathrm{Ph}^{+}$cells, their $\mathrm{P} / \mathrm{D}^{1}=1-20$ (Fig. $1 \mathrm{~b}$, Table 1 ). $\mathrm{P} \& \mathrm{D}$ of $\mathrm{Ph}^{+}$cells from other CML patients is associated with effective maturation only with $\mathrm{P} / \mathrm{D}^{2} \leq 1$. It corresponds to type $2 \mathrm{Ph}^{+}$cells $(\sim 30 \%$ of cases) (Fig. 2 b, Table 1). During P\&D, these indices vary in their limits of $P \& D$. The Figures 1, 2 and Table 1 show that the continuance of $\mathrm{P} \& \mathrm{D}$ of $\mathrm{Ph}^{+}$cells types 1 and 2 (7-14 days) is comparable with that for $1-2$ cell cycles of hematopoietic cell clon [3, 40, 41].

The $\mathrm{P} \& \mathrm{Ds}$ of most samples of $\mathrm{Ph}^{+}$cells are characterized by repeated alternations of efficient proliferation and efficient maturation with the prevalence of the proliferation rate and high $\mathrm{P} / \mathrm{D}$ index $\left(\mathrm{P} / \mathrm{D}^{1} \geq 1-4\right)$, or with the prevalence of the maturation rate and low $\mathrm{P} / \mathrm{D}$ index $(\mathrm{P} / \mathrm{D} \leq 1)$ (Fig. 3 , b, Fig. 4 , b and Tables 2, 3). These $\mathrm{Ph}^{+}$cells constitute type 3 of $\mathrm{Ph}^{+}$cells. The alternations of proliferation ( $1^{\text {st }}$ stage) and maturation ( $2^{\text {nd }}$ stage) are clearly identified by crossings of the kinetic plots of accumulation of proliferating ( $\mathrm{P}$ [immature]) and matureting (D [mature]) cells (Figs.3 and 4b, Table 3). Proliferation and maturation can be accompanied by $1-3$ such alternations that are changing each other according to the following schemes: $1 / 2-1 / 2 / 1$ or $2 / 1-2 / 1 / 2$, with frequency from 1 to 5 days, rarely 0.2-6 days (Tables 3 and 4). In alternation according to schemes $1 / 2-1 / 2 / 1$, the rates and, hence, cell concentrations, are changing in the following series: [immature] $>$ [mature] $\rightarrow$ [mature] $>$ [immature] $\rightarrow$ [immature] $>$ [mature] (Figs.3: 3.1- 3.4, b). In alternation according to schemes $2 / 1-2 / 1 / 2$, the rates and, hence, cell concentrations, are changing in the following series: [mature] $>$ [immature $] \rightarrow[$ immature $]>$ [mature $] \rightarrow$ [mature $]>$ [immature] (Figs.4: $3.10-3.12, b)$. $\mathrm{P} \& \mathrm{D}$ of $\mathrm{Ph}^{+}$cells type 1 and 2 can be considered as a particular case of prolonged alternation of proliferation or maturation of $\mathrm{Ph}^{+}$cells type 3 .
At the moment of crossing of effective proliferation and effective maturation plots, the alternation of stages, rate of $\mathrm{Ph}^{+}$cells accumulation, and other $\mathrm{P} \& \mathrm{D}$ parameters takes place. At the moment of crossing, the proliferation and maturation rates, as well as the indices of their efficiency, become equal. At that moment, $\mathrm{P} / \mathrm{D}=1.06 \pm 0.23$ regardless of scheme, time point, alternation sequence or cell concentration (Tables 2 and 3). These moments can be called critical or equilibrium points. Other characteristics that may be expected to be equal (concentrations of immature cells, mature neutrophils $\left(0.4-0.7 \times 10^{6} / \mathrm{ml}\right)$ and segmented neutrophils only $\left.\left(0.1-0.4 \times 10^{6} / \mathrm{ml}\right)\right)$ in fact were similar (Table 3). However, the prominent variations $\left(1.53-0.1 \times 10^{6} / \mathrm{ml}\right.$ for BM $3.5, \mathrm{~PB}$ $3.10,3.11$ and BM 3.12 in Table 3 ) suggest the concentration's dependence.

During alternations, the cell characteristics are continuously changing (Table 2). The parameters increase or decrease, passing maximums and minimums. These events are usually asynchronous (Fig. 1-4 and Table 2). The pattern of $\mathrm{P} / \mathrm{D}$ indices changing depends upon the stage. They vary within the limits $\mathrm{P} / \mathrm{D}^{1}=1-4, \mathrm{P} / \mathrm{D}^{2} \leq 1$. The only exception was BM № 3.3, where $\mathrm{P} / \mathrm{D}^{1}$ decreased from 11 to 13 days before it reaches a steady-state and the maturation stage begins. Under maturation, stage $\mathrm{P} / \mathrm{D}^{2}$ varies from 0.1 to 1 , untill a new proliferation stage with $\mathrm{P} / \mathrm{D}^{1}>1$. It means that the rates of proliferation and maturation - their P/D efficiency indices and concentrations of proliferating and maturating cells (especially segmented neutrophils) - are rather significant parameters of $\mathrm{Ph}^{+}$cells $\mathrm{P} \& \mathrm{D}$.

Analysis of the kinetics of granulocytes subpopulations development, the kinetics of apoptosis, and distribution of $\mathrm{Ph}^{+}$ cells in the cell cycle phases in combination with differences in $\mathrm{P} / \mathrm{D}$ index and the rates of proliferation and differentiation stages of $\mathrm{Ph}^{+}$cells $\mathrm{P} \& \mathrm{D}$ revealed the following. 
Table 2. Parameters of alternation for efficient proliferation and efficient maturation stages under condition of proliferation and differentiation of 3 type $\mathrm{Ph}^{+}$cells in the culture

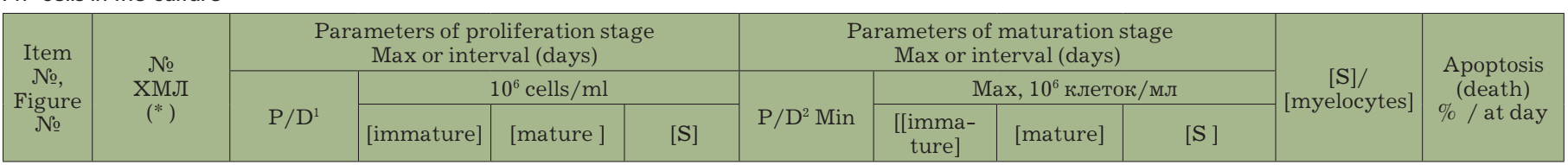

Alternation stages according to $1 / 2$ or $1 / 2 / 1$ schemes with changing accumulation rates and $\mathrm{Ph}^{+}$cell concentration $[$ immature $]>$ [mature $] \rightarrow$ [mature $]>$ [immature $] \rightarrow$ [immature $]>$ [mature $]$

\begin{tabular}{|c|c|c|c|c|c|c|c|c|c|c|c|}
\hline $\begin{array}{c}1, \\
\text { Fig. } 3\end{array}$ & 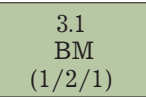 & $\begin{array}{l}1,4-1,1 \\
1,2-2,3\end{array}$ & $\begin{array}{l}0,35-0,5 \\
0,64-0,5\end{array}$ & $\begin{array}{l}0,29-0,5 \\
0,63-0,2\end{array}$ & $\begin{array}{l}0,1-0,25 \\
0,3-0,1\end{array}$ & $\begin{array}{c}0,9 \\
\text { (at } 3 \text { day) }\end{array}$ & $\begin{array}{c}0,71 \\
\text { (at } 3 \text { day) }\end{array}$ & $\begin{array}{c}0,8 \\
\text { (at } 3 \text { day) }\end{array}$ & $\begin{array}{c}0,4 \\
\text { (at } 3 \text { day) }\end{array}$ & $0,5-0,2$ & $5-12$ \\
\hline $\begin{array}{c}2, \\
\text { Fig. } 3\end{array}$ & $\begin{array}{c}3.2^{* *} \\
\mathrm{~PB} \\
(1 / 2)\end{array}$ & $1,3-1,2$ & 0,4 & 0,30 & 0,05 & 0,85 & $0,4-0,3$ & 0,53 & 0,16 & $0,5-0,25$ & $<5$ \\
\hline $\begin{array}{c}3 \\
\quad 4 \\
\text { Fig.3 }\end{array}$ & $\begin{array}{c}3.3 \\
\text { BM } \\
\text { PB }(1 / 2)\end{array}$ & $\begin{array}{c}11-2 \\
1,32-1,5\end{array}$ & $\begin{array}{c}0,6-0,46 \\
0,5-0,8\end{array}$ & $\begin{array}{c}0,02-0,5 \\
0,4-0,5\end{array}$ & $\begin{array}{c}0,01-0,4 \\
0,14-0,25\end{array}$ & $\begin{array}{c}0,1 \\
1,0-0,2\end{array}$ & $\begin{array}{c}0,5-0,1 \\
0,5- \\
0,1\end{array}$ & $\begin{array}{c}0,6 \\
\text { (3 day) } \\
0,6 \\
\text { (7 day) }\end{array}$ & $\begin{array}{l}0,4-0,2 \\
0,3-0,2\end{array}$ & $\begin{array}{r}0,1-2,5 \\
0,1-1-2,5\end{array}$ & $\begin{array}{c}\text { (7 at } 11 \\
\text { day) }\end{array}$ \\
\hline $\begin{array}{c}5 \\
\text { Fig.3 }\end{array}$ & $\begin{array}{c}3.4 \\
\text { BM } \\
(1 / 2 / 1)\end{array}$ & $\begin{array}{c}1,2 \\
1,53\end{array}$ & $\begin{array}{c}0,4-0,8-0,5- \\
1,1\end{array}$ & 0,34 & 0,17 & $0,52-0,34$ & $0,57-0,34$ & 1,1 & 0,7 & $0,4-1,3-2$ & (18 at 5 day) \\
\hline 6 & $\begin{array}{c}3.5 \\
\text { BIM } \\
(1 / 2)\end{array}$ & $3,43-1,0$ & 1,95 & 1,65 & $\begin{array}{c}0,03- \\
0,37\end{array}$ & $1,0-0,3$ & $1,53-0,4$ & $1,53-1,21$ & $0.37-0,5$ & $0,19-0,25-2,0$ & $\begin{array}{l}\text { (30 at } \\
\text { 11day) }\end{array}$ \\
\hline 7 & $\begin{array}{c}3.6 \\
\text { BM } \\
(1 / 2)\end{array}$ & 1,61 & 0,61 & 0,52 & 0,24 & 0,28 & $\begin{array}{c}0,13- \\
0,56\end{array}$ & $\begin{array}{c}0,52-0,4- \\
0,6\end{array}$ & 0,24 & $0,13-0,5-1,0$ & $\begin{array}{l}\text { (22 at } 11 \\
\text { day) }\end{array}$ \\
\hline $\begin{array}{l}8 \\
9\end{array}$ & $\begin{array}{c}3.7 \\
\operatorname{BM}(1 / 2) \\
\operatorname{PB}(1 / 2 / 1)\end{array}$ & $\begin{array}{l}2,5-1,4 \\
2,2-1,2 \\
1,2-1,4\end{array}$ & $\begin{array}{l}0.65-0,60 \\
0,51-0,54 \\
0,38-0,32\end{array}$ & $\begin{array}{c}0,55 \\
0,5-0,54 \\
0,4-0,2\end{array}$ & $\begin{array}{c}0,3 \\
0,05-0,19 \\
0,15-0,07\end{array}$ & $\begin{array}{c}0,7-0,4 \\
0,78\end{array}$ & $\begin{array}{c}0,55 \\
0,57-0,38\end{array}$ & $\begin{array}{l}0,83 \\
0,73\end{array}$ & $\begin{array}{l}0,53 \\
0,27\end{array}$ & $0,1-0,5$ & $\begin{array}{c}(30-35 \text { at } \\
10-11 \text { day) }\end{array}$ \\
\hline 10 & $\begin{array}{c}3.8 \\
\operatorname{BM}(1 / 2)\end{array}$ & $3,9-1,5$ & $0,53-0,35$ & $0,14-0,35$ & $0,02-0,22$ & $1,5-0,5$ & $0,35-0,23$ & $0,35-0,44$ & $0,2-0,4$ & $0,04-0,3$ & (45 at 7 day) \\
\hline
\end{tabular}

Alternation stages according to $2 / 1$ or $2 / 1 / 2$ schemes with changing accumulation rates and $\mathrm{Ph}^{+}$cell concentration: $[$ mature $]>$ immature $] \rightarrow[$ immature $]>[$ mature $] \rightarrow[$ mature $]>$ [immature $]$

\begin{tabular}{|c|c|c|c|c|c|c|c|c|c|c|c|}
\hline $\begin{array}{c}11 \\
\text { Fig. } 4\end{array}$ & $\begin{array}{c}3.10^{*} \\
\mathrm{~PB} \\
(2 / 1) \leftrightarrow\end{array}$ & $1,4-3,1-2,0$ & $\begin{array}{c}0,3-0,6 \\
-0,4\end{array}$ & $0,3-0,2$ & $0,17-0,25$ & $0,2-0,5$ & $0,13-0,3$ & $0,5-0,8-0,3$ & $0,35-0,7$ & $8,5-0,3$ & $\begin{array}{l}34-22 \text { at } \\
2-5 \text { days }\end{array}$ \\
\hline $\begin{array}{c}12, \\
\text { Fig. } 4\end{array}$ & $\begin{array}{c}3.11 \\
\mathrm{~PB} \\
(2 / 1 / 2) \leftrightarrow\end{array}$ & $1,15-1,63$ & $0,8-0,6$ & $0,6-0,8-0,1$ & $0,43-0,3$ & $\begin{array}{c}0,33-1,15 \\
0,75-0,8\end{array}$ & $\begin{array}{c}0,2-0,8 \\
0,6-0.8-0,1\end{array}$ & $\begin{array}{c}0,5-1,3-0,8 \\
0,8-0,1\end{array}$ & $\begin{array}{c}0,16-0,75-0,4 \\
0,39-0,06\end{array}$ & $1,2-0,2$ & $\begin{array}{l}35 \text { at } 1 \text { day, } \\
63 \text { at } 4 \text { days }\end{array}$ \\
\hline $\begin{array}{c}\text { 13, } \\
\text { Fig. } 4\end{array}$ & $\begin{array}{c}3.12 \\
\text { BM } \\
(2 / 1 / 2 / 1 / 2) \\
\leftrightarrow\end{array}$ & $\begin{array}{c}1,0-1,32 \\
1,0\end{array}$ & $\begin{array}{c}0,7-0,78 \\
0,24\end{array}$ & $\begin{array}{c}0,6 \\
0,24\end{array}$ & $\begin{array}{c}0,14-0,35 \\
0,12\end{array}$ & $\begin{array}{c}0,5-0,7-1,0 \\
1,0-0,8- \\
1,0\end{array}$ & $\begin{array}{c}0,6-0,7 \\
0,6 \\
0,2\end{array}$ & $\begin{array}{c}0,4--0,95 \\
0,6\end{array}$ & $\begin{array}{c}0,14-0,5 \\
0,34 \\
0,1 \\
\end{array}$ & $0,9-0,2$ & $\begin{array}{c}7,22 \text { at } 6 \\
11 \text { days }\end{array}$ \\
\hline 14 & $\begin{array}{c}3.13 \\
\mathrm{~PB} \\
(2 / 1) \\
\leftrightarrow\end{array}$ & $1,7-2,5$ & 0,39 & $0,4-0,2$ & $0,2-0,1$ & $0,45-1,7$ & 0,42 & $0,9-0.4$ & $0,3-0,2$ & $0,9-1-9$ & $\begin{array}{c}\text { (48 at } 8 \\
\text { days) }\end{array}$ \\
\hline 15 & $\begin{array}{c}3.14 \\
\text { BM } \\
(2 / 1) \\
\leftrightarrow\end{array}$ & $1,0-1,34$ & $0,6-0,5$ & 0,4 & $0,4-0,2$ & $1,1-0,7$ & $0,4-1,0$ & $0,4-1,37$ & $0,12-0,92$ & $0,3-1,0$ & $\begin{array}{c}\text { (45 at } 5 \\
\text { days) }\end{array}$ \\
\hline
\end{tabular}

Footnote: *alternation scheme; **acceleration phase; BM - bone marrow, PB- peripheral blood; brackets [ ] show cell concentration; hyphen interval of values on the kinetic plots; Figure $\leftrightarrow$ shows that $1^{\text {st }}$ stages data for alternation $2 / 1$ and $2 / 1 / 2 / 1$ are given earlier than that of $2 \mathrm{~d}$ stages according to the subtitle of the table.

Proliferation and differentiation of type $1 \mathrm{Ph}^{+}$cells prolonged effective proliferation with $\mathrm{P} / \mathrm{D}$ index $>1-2 \div 20$ and amount of $\mathrm{Ph}^{+}$cells in $\mathrm{S}+\mathrm{G} 2 / \mathrm{M}$ phases $\geq 20-45 \%$; the proliferation rate prevails over maturation (Figs.1.2, 1.3.a ,b, c). P\&D is associated with enhanced accumulation of myelocytes, promyelocytes, and/or blasts and low accumulation of neutrophils, maturing without dividing (Figs.1, $a, b,: 1.1-1.3$ and 1.4 in Table 1 ) and with a high level of apoptosis (Fig.1, c). The lower neutrophils content characterizes the higher P/D index (Fig.1: 1.1-1.3, b) and CML progression (Table 1). These $\mathrm{Ph}^{+}$cells were isolated from the $\mathrm{PB}$ and $\mathrm{BM}$ of $\mathrm{CML}$ patients at all phases of the disease during progression and amounts to one-fifth of all studied samples of $\mathrm{Ph}^{+}$cells. 

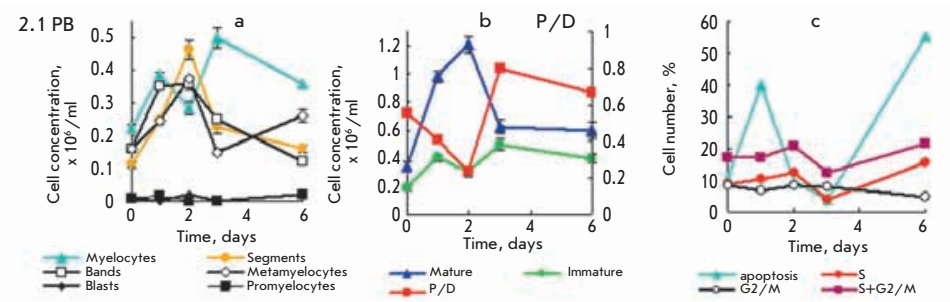

$2.2 \mathrm{BM}$
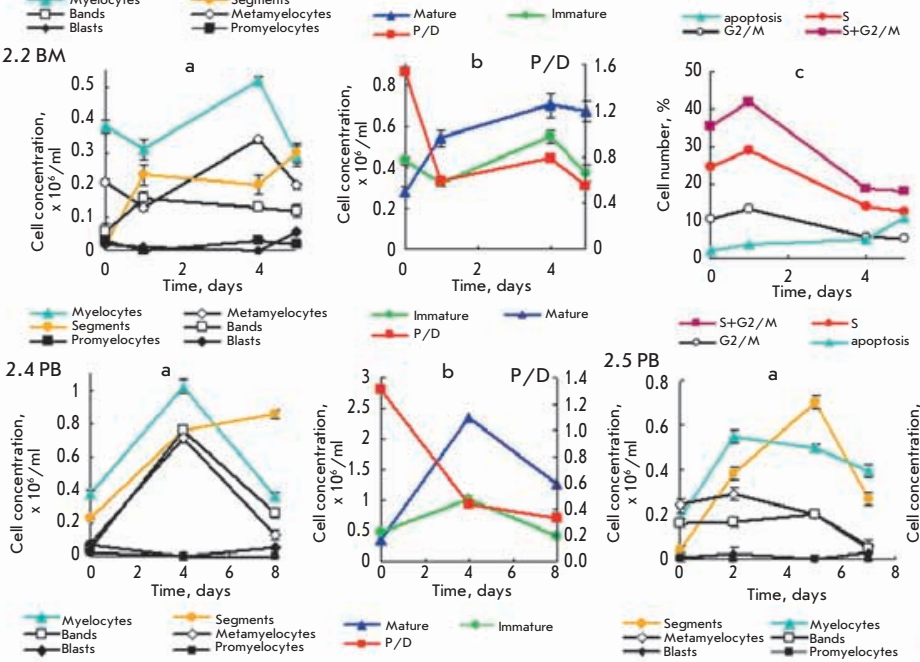

$\nsubseteq-M a t$
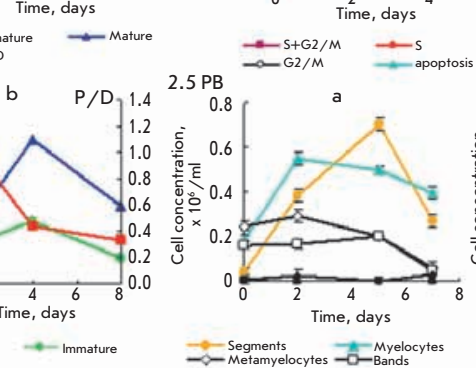

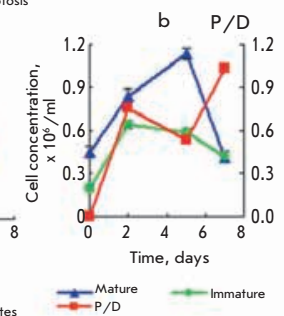

Fig. 2. Kinetic plots of formation and transformation of type $2 \mathrm{Ph}^{+}$cells subpopulations as well as kinetics plots of their proliferation and maturation (as accumulating and consuming) in the suspension culture of mononuclears isolated from bone marrow (BM) or peripheral blood (PB) of chronic myeloid leukemia (CML) patients $\mathrm{a}-$, b-, c- the same as in Fig. 1. 2.1 PB, 2.2 BM, 2.4 PB and 2.5 PB - samples of cells from corresponding CML CP patients. The prolonged observation didn' $\dagger$ reveal signs of CML progression. Samples characteristics, as well as proliferation and maturation data of type $2 \mathrm{Ph}^{+}$cells, are shown in Table 1

Proliferation and differentiation of type $2 \mathrm{Ph}^{+}$cells is characterized by low efficiency (index $\mathrm{P} / \mathrm{D} \leq 1$ ) with the prevalence of the maturation rate over the proliferation rate and apoptosis blocking. $\mathrm{P} \& \mathrm{D}$ of type $2 \mathrm{Ph}^{+}$cells is associated with prominent neutrophils accumulation inhibiting the $\mathrm{Ph}^{+}$cells proliferation (Fig.2, Table 1). Apoptosis inhibition during neutrophils maturation is not synchronous to myelocytes accumulation and induction of apoptosis. The decrease of the $\mathrm{P} / \mathrm{D}$ index is associated with neutrophiles accumulation; the increase of $P / D$, with depletion of segmented neutrophils (Figs.2, a b, c; 2.1 - 2.7, Table 1). The mature neutrophils concentration is significantly higher than that of proliferating $\mathrm{Ph}^{+}$cells.

An important characteristic of proliferation is the distribution of cells in the cell cycle phases. The kinetic plots of type $2 \mathrm{Ph}^{+}$granulocytes distribution in the $\mathrm{S}$ and $\mathrm{G} 2 / \mathrm{M}$ phases show that their changing during proliferation and maturation depends upon their source-CML patient. Figure .2.1, 2.2, c shows that the portion of proliferating $\mathrm{Ph}^{+}$cells in phases $\mathrm{S}+\mathrm{G} 2 / \mathrm{M} \leq 20-40 \%$; and in $\mathrm{G} 2 / \mathrm{M}$ phase, $\sim 15 \%$. Another proliferative index $-\mathrm{S} /(\mathrm{G} 2+\mathrm{M})$ ratio is 1.2 . The maximum percentage of cells in $\mathrm{S}+\mathrm{G} 2 / \mathrm{M}$ at day 1 was $43 \%$; and in $\mathrm{S}$ phase, $\sim 30 \%$, rapidly declining to $12 \%$. $\mathrm{P} / \mathrm{D}$ index at the same time is 0.6-0.8 (Fig. 2.2 b). The percentage of proliferating types 1 and $2 \mathrm{Ph}^{+}$cells is similar (Fig. $2.2 \mathrm{c}$ and Fig. $1.2 \mathrm{c}$ ). But the duration of elevated percentage of cells in $\mathrm{S}+\mathrm{G} 2 / \mathrm{M}$ phases in type 2 $\mathrm{Ph}^{+}$cells is shorter than in type 1 , where the portion of proliferating cells $\geq 43 \%$ is maintained for nearly 6 days with the $S$ / $(\mathrm{G} 2+\mathrm{M})$ ratio $\sim 2.4-2.7$ and $\mathrm{P} / \mathrm{D}$ efficiency $1.2-1.6$. In terms of $\mathrm{P} \& \mathrm{D}$ of type $2 \mathrm{Ph}^{+}$cells, that means the prevalence of maturation over proliferation. Under cultivation, the percentage of proliferating malignant $\kappa 562$ cells (derivate of CML blastic phase) in $\mathrm{S}+\mathrm{G} 2 / \mathrm{M}$ phases reaches $44 \pm 3 \%$ with little changes in the next 7 days. The $\mathrm{S} /(\mathrm{G} 2+\mathrm{M})$ ratio at that time reaches 4.4. For comparison with these values, the $\mathrm{P} \& \mathrm{D}$ of type $2 \mathrm{Ph}^{+}$ cells is characterized by a decreased percentage of cells in $\mathrm{S}+\mathrm{G} 2 / \mathrm{M}$ phases $(<20-40 \%)$ with a shortened duration of proliferation ( $<3$ days) and low $\mathrm{P} / \mathrm{D}$ efficiency $\leq 1$ (Figs.2.1 and $2.2, \mathrm{~b}, \mathrm{c})$.

The kinetic plots of type $2 \mathrm{Ph}^{+}$leucocytes differentiation show $\sim 80 \%$ granulocytes content, while the percentage of myelocytes is not more than $25 \%$. The percentage of mature neutrophils, especially segmented, reaches $\sim 40 \%$ (Figs.2.12.5, $\mathrm{b}$ and 2.1-2.6 in Table 1). During P\&D, all neutrophils are actively accumulated with little consumption. The maximal concentration of segmented neutrophils at times is twice that of myelocytes (Figs 2.1-2.5 a, b, c, and Table 1), emphasizing the role of mature cells (especially segmented neutrophils) in the regulation of $\mathrm{P} \& \mathrm{D}$ of type $2 \mathrm{Ph}^{+}$cells.

In summary, the population of type $2 \mathrm{Ph}^{+}$leucocytes increases by 2-4 times under low $\mathrm{P} / \mathrm{D}$ efficiency and a proliferation rate lower than that of maturation. It is associated with the accumulation of neutrophils (especially segmented), the decrease of the myelocyte content, and apoptosis inhibition. It means that the excessive accumulation of neutrophils (due to apoptosis blockage) inhibits the proliferation of their own precursors and the differentiation of neutrophils (metamyelocytes, band and segmented), probably through a feedback mechanism

The ratio $[\mathrm{S}] /[\mathrm{M}]$ is usually a small value; during proliferation and differentiation of type 2 cells, it increases, exceeds 1 , and reflects the accumulation of segmented neutrophils, synchronous to the decrease of myelocytes accumulation. The neutrophils accumulation reaches a maximum at day 2 or 4 (Fig.2: a, b) that corresponds to a minimum accumula- 
Table 3. The characteristics of crossings at alternation of proliferation and maturation stages during P\&D of type 3 Ph ${ }^{+}$cells in culture. See notes to Table 2

\begin{tabular}{|c|c|c|c|c|c|c|c|c|c|c|c|}
\hline \multirow{3}{*}{$\begin{array}{c}\mathrm{N} \\
\text { Fig. }\end{array}$} & \multirow{3}{*}{$\begin{array}{l}\text { N CML } \\
\text { patient }\end{array}$} & \multirow{3}{*}{$\begin{array}{c}\text { Stage } \\
\text { alternation } \\
\text { scheme }\end{array}$} & \multicolumn{5}{|c|}{$\begin{array}{l}\text { Crossings of accumulation rate plots for proliferating [immature] (stage } \\
\text { 1) and maturating cells [mature] (stage 2) }\end{array}$} & \multicolumn{4}{|c|}{$\begin{array}{l}\text { Cell concentration in crossings, } 10^{6} \\
\text { cells } / \mathrm{ml}\end{array}$} \\
\hline & & & $\begin{array}{c}\text { Time of crossing, } \\
\text { Day }\end{array}$ & $\begin{array}{l}\text { Stages duration, } \\
\text { days }\end{array}$ & \multicolumn{3}{|c|}{$\begin{array}{l}\mathrm{P} / \mathrm{D} \text { indices in crossing } \\
\text { points } \mathrm{N}\end{array}$} & \multicolumn{2}{|c|}{$\begin{array}{l}\text { Mature and } \\
\text { immature }\end{array}$} & \multirow{2}{*}{\multicolumn{2}{|c|}{$\begin{array}{cc}\text { Segmented }(\mathrm{S}) \\
1\end{array}$}} \\
\hline & & & $1 \quad 2$ & $1 \quad 2$ & $1^{p}$ & & 3 & 1 & 2 & & \\
\hline 1 Fig.3 & $3.1 \mathrm{M}$ & $1 / 2 / 1$ & $2 ; \quad 3,5$ & $2 ; \quad 2^{1,5}$ & 1,1 & 1,2 & - & 0,5 & 0,65 & 0,24 & 0,34 \\
\hline 2 Fig.3 & $3.2 \mathrm{~PB}$ & $1 / 2$ & 2,5 & 2,$5 ; \quad>4,5$ & 1,06 & - & - & 0,4 & - & 0,1 & - \\
\hline $\begin{array}{l}3 \\
4\end{array}$ & $\begin{array}{l}\text { 3.3 BM } \\
\mathrm{PB}\end{array}$ & $\begin{array}{l}1 / 2 \\
1 / 2\end{array}$ & 2,5 & $\begin{array}{ll}2,5 ; & 8,5 \\
5,5 ; & 5,5\end{array}$ & $\begin{array}{l}\sim 2 \\
1,0\end{array}$ & - & - & 0,49 & - & $\begin{array}{l}0,26 \\
0,38\end{array}$ & - \\
\hline 5 Fig. 3 & $3.4 \mathrm{BM}$ & $1 / 2 / 1$ & 0,2 & $\sim 0,2 ; \quad 5,8$ & 1,15 & 1,2 & - & 0,37 & 0,8 & 0,17 & 0,58 \\
\hline 6 & $3.5 \mathrm{BM}$ & $1 / 2$ & 5 & 5 & 1,0 & - & - & 1,53 & - & 0.37 & - \\
\hline 7 & $3.6 \mathrm{BM}$ & $1 / 2$ & 4,5 & 4,5 & 1,06 & - & - & 0,53 & - & 0,24 & - \\
\hline $\begin{array}{l}8 \\
9\end{array}$ & $\begin{array}{c}3.7 \mathrm{BM} \\
\mathrm{PB}\end{array}$ & $\begin{array}{c}1 / 2 \\
1 / 2 / 1\end{array}$ & $\begin{array}{rc}2,5 ; & - \\
2,5 ; & 8,5\end{array}$ & $\begin{array}{ll}2,5 ; & 8,5 \\
2,5 ; & 8,5\end{array}$ & $\begin{array}{l}1,5 \\
1,2\end{array}$ & - & - & $\begin{array}{l}0,53 \\
0,54\end{array}$ & 0,4 & $\begin{array}{l}0,4 \\
0,17\end{array}$ & $\begin{array}{r}- \\
0,15\end{array}$ \\
\hline 10 & $3.8 \mathrm{BM}$ & $1 / 2$ & 5 & $5 ; \quad>2$ & 1,5 & - & - & 0,35 & - & 0,15 & - \\
\hline $\begin{array}{c}11 \\
\text { Fig.4 }\end{array}$ & $3.10 \mathrm{~PB}$ & $2 / 1 \leftrightarrow$ & 3 & 4 & 1,4 & - & - & 0,33 & - & 0,3 & - \\
\hline $\begin{array}{c}12 \\
\text { Fig.4 }\end{array}$ & $3.11 \mathrm{~PB}$ & $\underset{\leftrightarrow}{2 / 1 / 2 / 1}$ & 5,$5 ; \quad 7,5 ; \quad 11$ & $\begin{array}{ll}2 ; & 5,5 \\
0 ; & 3,5\end{array}$ & 1,15 & 1,15 & 0,80 & 0,75 & $1^{0,6}$ & $\begin{array}{r}0,43 ; \\
0,0\end{array}$ & $6^{0,3}$ \\
\hline $\begin{array}{c}13 \\
\text { Fig.4 }\end{array}$ & $3.12 \mathrm{BM}$ & $\begin{array}{c}2 / 1 / 2 / 1 / 2 \\
\leftrightarrow\end{array}$ & 4,$5 ; \quad 6 ; \quad 08$ & $\begin{array}{c}4,5 \\
2,5 \\
1\end{array}$ & $\begin{array}{l}1,05 \\
1,0\end{array}$ & 1,0 & 1,0 & $\begin{array}{l}0,62 \\
0,24\end{array}$ & $\begin{array}{l}0,72 \\
0,24\end{array}$ & $\begin{array}{l}0,13 \\
0,11\end{array}$ & $\begin{array}{l}0,35 \\
0,34\end{array}$ \\
\hline 14 & $3.13 \mathrm{~PB}$ & $2 / 1 \leftrightarrow$ & 4,0 & 1 & 1,7 & - & - & 0 , & & 0,2 & \\
\hline 15 & $3.14 \mathrm{BM}$ & $2 / 1 \leftrightarrow$ & 4,0 & 1 & 1,0 & - & - & 0 , & & 0,4 & \\
\hline
\end{tabular}

The mean value of $P / D$ efficiency index at crossings of proliferation and maturation rate plots at alternation stages 1 and 2 is $1.06 \pm 0.23(21,7 \%)$. BM - bone marrow, PB- peripheral blood; brackets [ ] show cell concentration; hyphen - interval of values on the kinetic plots; Figure $\leftrightarrow$ shows that $1^{\text {st }}$ stages data for alternation $2 / 1$ and $2 / 1 / 2 / 1$ are given earlier than that of $2 \mathrm{~d}$ stages according to the subtitle of the table.

tion of myelocytes and low $\mathrm{P} / \mathrm{D}$ index. Figure $2 \mathrm{a}$, $\mathrm{b}$ shows the increase of the $\mathrm{P} / \mathrm{D}$ index because of $\mathrm{D}$ cells concentration decrease at day 4 .

The content of type $2 \mathrm{Ph}^{+}$cells is one-third of all studied samples; all of them isolated from CML chronic phase (CP) patients. The clinical observation of CML patients with type $2 \mathrm{P} \& \mathrm{D}$ shows prolonged life duration in case of successful therapy.

Proliferation and differentiation of type $3 \mathrm{Ph}^{+}$cells takes place as repeated alternation of proliferation (stage 1) with maturation (stage 2) and changing of the $\mathrm{P} / \mathrm{D}$ efficiency index from $\mathrm{P} / \mathrm{D}^{1}>1$ to $\mathrm{P} / \mathrm{D}^{2} \leq 1$ etc. (Tables 2 and 3 ). At the first stages of alternation, the myelocytes accumulation under activ apoptosis prevails over the accumulation of maturating neutrophils. Second stages of alternation are characterized by efficient maturation with apoptosis blockage and accumulation of enhanced concentration of neutrophils that inhibits further proliferation (Fig. 3, 4 and Tables 2 and 3). It is accompanied by an inversion of the sequence of neutrophils accumulation, as in the $\mathrm{P} \& \mathrm{D}$ of type $2 \mathrm{Ph}^{+}$cells (Figs. $2-4 \mathrm{a}$, b, c) considered below.

The transition to the next alternation stage 1 according to schemes $1 / 2 / 1$ and $2 / 1 / 2$ is associated with apoptosis induction, depletion of segmented neutrophils, and accumulation of immature $\mathrm{Ph}^{+}$cells. Thus, at the crossing of the proliferation and maturation plots, the effective proliferation changes to effective maturation and vice versa; the characteristics and parameters of the same (but already passed) stage are restored.

The $\mathrm{P} / \mathrm{D}$ efficiency indices depend upon the alternation stage, as discussed above (Tables 2 and 3 ). At the first stages, index $\mathrm{P} / \mathrm{D}^{1}>1$; at next stages, $\mathrm{P} / \mathrm{D}^{2} \leq 1$.

The alternation of the highly effective proliferation of $\mathrm{Ph}^{+}$ cells and relatively ineffective neutrophils maturation results in increasing and decreasing P/D efficiency (Table 3 and Figs. 3 and 4). It allows to maintain a moderate efficiency of $P \& D$ on the whole. It corresponds to alternating changing of type 3 $\mathrm{Ph}^{+}$cells parameters (Tables 2 and 3 ). Taken together, these results mean alternation between the efficient proliferation and efficient maturation of the participation of segmented and other mature neutrophils in the regulation of type $3 \mathrm{Ph}^{+}$ cells $\mathrm{P} \& \mathrm{D}$ through inhibition of $\mathrm{Ph}^{+}$cells proliferation at the maturation stage. A similar regulation can be seen during $\mathrm{P} \& \mathrm{D}$ of type $2 \mathrm{Ph}^{+}$cells.

Alternating efficient proliferation and efficient maturation according to $1 / 2$ scheme, beginning from stage 1 (Fig. 3.6, Table 2), have $\mathrm{P} \& \mathrm{D}$ characteristics compatible to type 1 $\mathrm{Ph}^{+}$cells. The content of myelocytes and proliferating cells in $\mathrm{S}+\mathrm{G} 2 / \mathrm{M}$ phases increases, > 30-45\%, at days 1-2 (Fig. 3), while the neutrophils content drops. At stage 2 of alternation, the segmented neutrophils concentration increases, the $\mathrm{P} / \mathrm{D}^{2}$ index drops $\leq 1$, the myelocytes content drops, and the percentage of $\mathrm{Ph}^{+}$cells in $\mathrm{S}+\mathrm{G} 2 / \mathrm{M}$ phases becomes $\leq 25 \%$. At the beginning of the next stage 1 - the proliferation stage that 

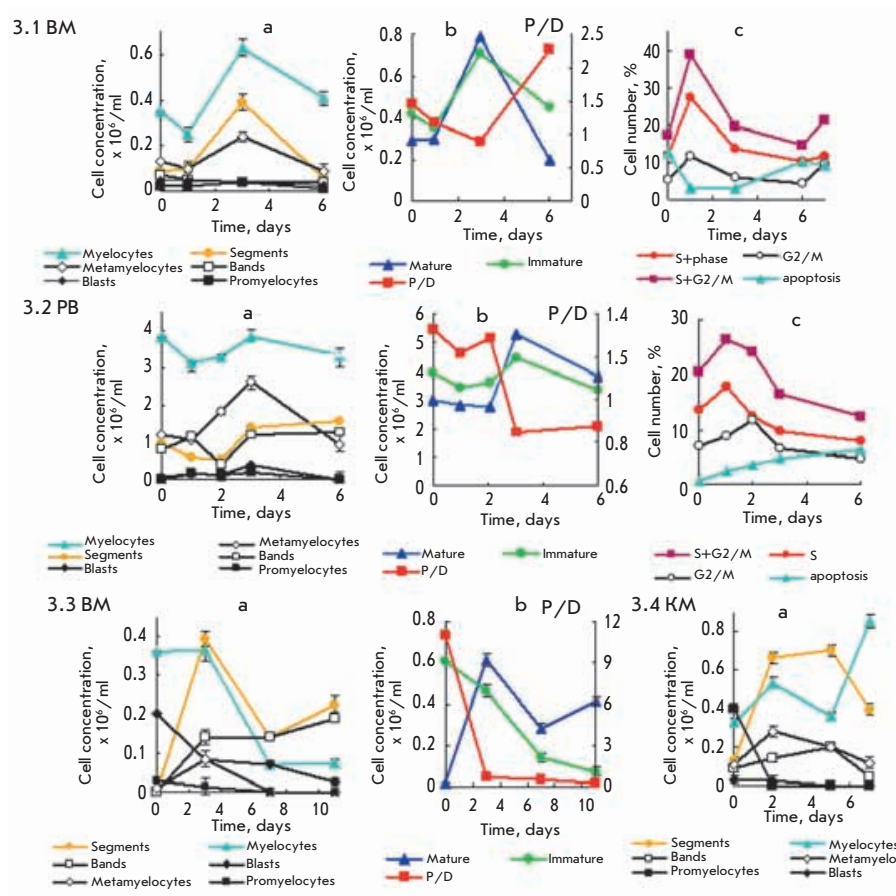

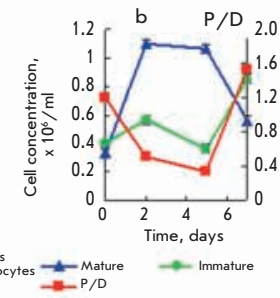

Fig.3. Kinetic plots of proliferation and maturation of type $3 \mathrm{Ph}^{+}$cells with alternating efficient proliferation and efficient maturation stages according to $1 / 2$ or $1 / 2 / 1$ scheme in the suspension culture of mononuclear from $\mathrm{BM}$ or $\mathrm{PB}$ of $\mathrm{CML}$ patients

$\mathrm{a}-, \mathrm{b}-, \mathrm{c}-$ the same as at Fig. 1. $\mathrm{Ph}^{+}$cell $3^{\mathrm{d}}$ type $3.1 \mathrm{BM}$, 3.2 PB, 3.2 BM, 3.3 BM and 3.4 BM - samples of cells from corresponding CML CP patients. Parameters characteristics of efficient proliferation and efficient maturation for this $\mathrm{Ph}^{+}$cell type are shown in Tables 2 and 3 happened at day 7 - the percentage of cells in the $\mathrm{S}+\mathrm{G} 2 / \mathrm{M}$ phases again begins to increase (Fig. 3.1 c) and other parameters of stage 1 restore. The alternation of stages 1 and 2 is analogous to the $\mathrm{P} \& \mathrm{D}$ of $\mathrm{Ph}^{+}$cells types 1 and 2, correspondingly, but their duration is shorter. The overall duration of stage 1 of $\mathrm{Ph}^{+}$cells type 3 is $4-5$ days -3 times as much as in its stage 2 (Table 3 ).

The second stage of alternation of the $\mathrm{P} \& \mathrm{D}$ of type $3 \mathrm{Ph}^{+}$ cells $-\mathrm{Ph}^{+}$cells corresponds to $\mathrm{P} / \mathrm{D}^{2} \leq 1$ values, high segmented neutrophils concentrations, apoptosis block, and minimal concentration of myelocytes (Fig. 4 a, b, c and № 3.10-3.14 in Table 2). Under apoptosis induction and decrease of segmented neutrophils concentration, accumulation of myelocytes and the $\mathrm{P} / \mathrm{D}^{1}$ index again begin to increase. The maximums of $\mathrm{P} / \mathrm{D}^{1}$ and myelocytes accumulation coincide with minimum segmented neutrophils concentration at day 5 . The mature neutrophils accumulation leads to a drop in $\mathrm{P} / \mathrm{D}^{1}$, decrease of myelocytes concentration, and establishment of the efficient maturation stage. These properties are coherent with the characteristics of the $\mathrm{P} \& \mathrm{D}$ of type $2 \mathrm{Ph}^{+}$cells and other patient cells with $\mathrm{P} \& \mathrm{D}$ type 3 , according to the $2 / 1 / 2$ alternation scheme (Fig. 4 a, b, c; other samples data in Table 2).

Inhibition of apoptosis and myelocytes proliferation by segmented neutrophils is clearly seen in Figures 3 and $4 \mathrm{a}, \mathrm{b}$, c, etc. in Table 2. At the same time, the more active the $\mathrm{Ph}^{+}$ cells proliferation and apoptosis, the higher is the $\mathrm{P} / \mathrm{D}^{1}$ index (for example, Fig.3 a, b, c, and Table 2).

The distinctive feature of type $3 \mathrm{Ph}^{+}$cells $\mathrm{P} \& \mathrm{D}$ according to the $2 / 1 / 2$ scheme, beginning with stage 2 , is in a prompt and significant accumulation of segmented neutrophils at the beginning of $\mathrm{P} \& \mathrm{D}$ and in prominent apoptosis blocking, especially $\mathrm{Ph}^{+}$cells proliferation inhibition and distortion of matu- ration. The apoptosis rate reaches a maximum at 2-5 days and equals $\sim 35 \%$ (Fig. 4 , a-c), corresponding by P\&D time to the depletion and complete death of segmented neutrophils. At the beginning, maximum cell proliferation at the maturation stage is due to the accumulation and depletion of segmented neutrophils; the second maximum of $\mathrm{Ph}^{+}$cells proliferation is already observed due to transition to the efficient proliferation stage after the death of segmented neutrophils (Fig.4: $3.10, \mathrm{c})$.

The percentage of cells in particular cell cycle phases for $2 / 1$ and $2 / 1 / 2$ alternations is also linked to segmented neutrophils accumulation and corresponds to a decreased cell number in S+G2/M phases. In Figure 4, a-c, one can see maximums at day $1 \sim 10 \%$ (Fig.4: $3.10 \mathrm{BM}$ ), $25 \%$ (3.11 PB), and less than $5 \%$ (3.12 BM). At days 2-10, the portion of this pool significantly decreases. Under the next short proliferation stage at days 10-11, it slightly increases with a simultaneous increase of the $\mathrm{P} / \mathrm{D}^{1}$ index. Taken together with the decrease of $\mathrm{P} / \mathrm{D}^{2}$, it means the inhibition of $\mathrm{Ph}^{+}$cells proliferation by neutrophils, more prominent with a more frequent alternation of prolonged maturation stages.

Figures 4: 3.12, a-c indicate that under alternation of $2 / 1 / 2 / 1$ stages inhibition of proliferation proceeds with $\mathrm{P} /$ $\mathrm{D}^{2}=0.1-0.9$. Under these alternations, the cell number in the $\mathrm{S}+\mathrm{G} 2 / \mathrm{M}$ phases is $5 \%$ lower for eleven days. At low proliferation at the maturation stage, the apoptosis rate is less than $10 \%$; at days $6-11$, it increases only to $20 \%$ and only at the transition to stage 1. Overall, the time $\mathrm{Ph}^{+}$cells № 3.12 stay under the effective maturation stage is three times longer than at stage 1 . It leads to the most prominent inhibition of proliferation and apoptosis in type $3 \mathrm{Ph}^{+}$cells. In Figures 4: $3.11 \mathrm{a}, \mathrm{b}, \mathrm{c}$, maximum apoptosis corresponds to minimum 
segmented neutrophils accumulation, maximum myelocytes accumulation, and $\mathrm{P} / \mathrm{D}$ index rise. Type 3 of $\mathrm{P} \& \mathrm{D}$ was found in $\sim 50 \%$ of the $\mathrm{Ph}^{+}$cells studied (all from CML chronic phase patients). Among them, $2 / 3$ constitute $\mathrm{Ph}^{+}$cells with alternation of $1 / 2$ and $1 / 2 / 1$ stages.

Apoptosis block segmented neutrophils accumulation and inhibition of $\mathrm{Ph}^{+}$cells types 2 and 3 proliferation by neutrophils during effective maturation. The maturating neutrophils differentiate in the sequence $\mathrm{M} \rightarrow \mathrm{MM} \rightarrow \mathrm{B} \rightarrow \mathrm{S}$ with consequent apoptosis of segmented neutrophils. The accumulation of maturating neutrophils decreases in the order $\mathrm{S}>\mathrm{B}>\mathrm{MM}$ [3]. If the transport of neutrophils to other tissues is impossible, they should die by apoptosis; therefore, the observed prominent $\mathbf{S}$ accumulation means the block of apoptosis.

The maturation of $\mathrm{Ph}^{+}$cells type 2 and at $2^{\text {nd }}$ alternation stages of $\mathrm{Ph}^{+}$cells type 3 is associated with apoptosis blockage, elevation of mature neutrophils concentration, inhibition of myelocytes accumulation and decrease of the percentage of cells in $\mathrm{S}+\mathrm{G} 2 / \mathrm{M}$ and/or shortening of their staying in those phases. These events explain the inhibition of proliferation by neutrophils with blocking of apoptosis. It should be noted that apoptosis induction is usually observed under depletion of cytokines in cultural media [16-18, 25, 26, 29, 43-45]. During maturation stages of $\mathrm{P} \& \mathrm{D}$ for $\mathrm{Ph}^{+}$cell, apoptosis is blocked without addition of cytokines in cultural media.

At $\mathrm{S}$ concentration $\sim 2-3 \times 10^{5}$ cells $/ \mathrm{ml}$ and high $\mathrm{S}+\mathrm{G} 2 / \mathrm{M}$ cells content, the apoptosis rate is low $(<5-10 \%)$; at day 5 , it hardly reaches $10 \%$ (Fig. 2.2 a,c). Cell death in other cases (by trypane blue staining) is also inhibited. In cases 2.2-2.4 BM and 2.6 PB, the apoptosis level didn't exceed 10-20\% (Table 1). As one can see in Figure $2.1 \mathrm{a}$, c, at day 1 of proliferation, the maximum apoptosis level reached $40 \%$ and $60 \%$ at day 6 with synchronous increase of myelocytes accumulation. It means that inhibition of myelocytes accumulation depends upon apoptosis blocking not directly but is rather mediated by the neutrophils accumulating due to the lack of apoptosis.

During P\&D of type $2 \mathrm{Ph}^{+}$cells, segmented neutrophils are even capable of accumulating with a separate peak at days 2-6 (with [S] $>0,2-0,3 \times 10^{6} / \mathrm{ml}$ ), as can be seen in Figures 2 a, b. It corresponds to a low apoptosis level and minimum myelocytes accumulation (Figs. $2.1 \mathrm{~b}, \mathrm{c}$ ). The myelocytes accumulation plot is broken for the period of significant $\mathbf{S}$ accumulation (with a maximum at day 2), while the $\mathrm{P} / \mathrm{D}$ index decreases. Myelocytic proliferation is inhibited until the segmented neutrophils concentration decreases due to apoptosis. After the death of a significant part of $\mathrm{S}$, the pattern of myelocytes accumulation restores and the P/D index increases (Figs. $2.1 \mathrm{~b}$ ), but it remains $\leq 1$. The maximum of $\mathrm{S}$ accumulation (Figs. 2.1 $\mathrm{a}, \mathrm{b}, \mathrm{c}$ ) at days 1 and 5 also corresponds to the minimum of myelocytes accumulation, lowering of $\mathrm{P} / \mathrm{D}$, and activation of apoptosis. A similar $\mathrm{S}$ accumulation (at days 2-5) inhibits myelocytes accumulation and decreases $\mathrm{P} / \mathrm{D}$, as can be seen in Figures $2.5 \mathrm{a}, \mathrm{b}$. The death of $\mathrm{S}$ at day 5 restores the increase of myelocytes concentration and P/D value. Figures $2.2 \mathrm{a}, \mathrm{b}$ show that maximum $\mathrm{S}$ accumulation corresponds to minimum accumulation of myelocytes; i.e., maximum inhibition of myelocytes accumulation. At the same time, maximums of myelocytes accumulation and apoptotic activity in Figures
$2.1 \mathrm{a}, \mathrm{b}, \mathrm{c}$ coincide. The same rule applies during $\mathrm{P} \& \mathrm{D}$ of type $3 \mathrm{Ph}^{+}$cells.

Thus, the low $\mathrm{P} \& \mathrm{D}$ efficiency of $\mathrm{Ph}^{+}$cells type 2 and type 3 at stages of effective maturation leads to prominent neutrophils accumulation, decrease of the proliferation rate, in comparison with the maturation rate, and decrease of of $\mathrm{Ph}^{+}$ cells proliferation. Inhibition of $\mathrm{Ph}^{+}$cells proliferation by neutrophils takes place under alternation of all stages of effective maturation and means the participation of neutrophils in the regulation of $\mathrm{Ph}^{+}$cells $\mathrm{P} \& \mathrm{D}$.

The regulation of $\mathrm{P} \& \mathrm{D} \mathrm{Ph}^{+}$cells types 2 and 3 consists of interdependent synchronous and asynchronous processes. Apoptosis inhibition with accumulation of neutrophils, maturing without dividing, proceeds asynchronously to myelocytes accumulation, apoptosis induction, and increasing efficiency. Myelocytes accumulation is synchronous with apoptosis induction, proliferation activation, and increase of $\mathrm{P} / \mathrm{D}$ efficiency.

Inversion of mature neutrophils accumulation order. Neutrophils maturing without dividing (D cells) by definition differentiates in the order $\mathbf{M} \rightarrow \mathbf{M M} \rightarrow \mathrm{B} \rightarrow \mathrm{S}$ with consequent apoptosis of $\mathbf{S}[3,40,41,45]$. Under an equal differentiation rate, it can be estimated to have the same order of accumulation. In some cases - at P\&D of type $1 \mathrm{Ph}^{+}$cells and effective proliferation stages in type $3 \mathrm{Ph}^{+}$cells - this order is actually observed.

During alternation at maturation stages of $\mathrm{Ph}^{+}$cells types 2 and 3, maximum and minimum values in the kinetic plots of neutrophils accumulation point to a change of their accumulation order (Figs. 2, 3 and 4, a). It means that the accumulation rate of $\mathrm{S}, \mathrm{B}$ and $\mathrm{MM}$ changes nonuniformly, and that their accumulation order is inverted. At that time, the accumulation of myelocytes decreases adjacent to the corresponding neutrophils peaks. Moreover, the order of neutrophils accumulation from the same $\mathrm{Ph}^{+}$cells inverts during the maturation process, restoring after the transition to proliferation stages.

Figure 2, a shows that order changes with increase or decrease of the neutrophils accumulation rate are frequent. It can be illustrated by the crossings of the neutrophils accumulation order plots with the inversion of their direction. For example, the order $\mathrm{M}>\mathrm{B}>\mathrm{MM} \sim \mathrm{S}$, visible at day 1 , consequentially inverts to $\mathrm{S}>\mathrm{MM} \sim \mathrm{B}>\mathrm{M}$ at day 2 , to $\mathrm{M}>\mathrm{B} \sim \mathrm{S}>\mathrm{MM}$ at day 3 , and to $\mathrm{M}>\mathrm{MM}>\mathrm{S}>\mathrm{B}$ at day 6 . In this figure the equal neutrophils accumulation rates after the crossing of plots at days 4-5 leads to an almost normal neutrophils accumulation order $-\mathrm{M}>>\mathrm{MM}>\mathrm{S} \geq \mathrm{B}$. In Figure $2: 2.1$, b one can see the usual accumulation order $-\mathrm{M}>\mathrm{MM}>\mathrm{B}>\mathrm{S}-$ at day 0 , but the inversion of this order leads to $\mathrm{M}>\mathrm{S}>\mathrm{B} \sim \mathrm{MM}$ at day 1 , then to $\mathrm{M}>>\mathrm{MM}>\mathrm{S}>\mathrm{B}$ at day 4 , and later to $\mathrm{S}$ accumulation with depletion of M, MM, and B. In Figure 2:2.4, a nearly equal accumulation rates of $3^{\text {rd }}$ neutrophils at day $4(\mathrm{M}>\mathrm{B} \sim \mathrm{S} \sim \mathrm{MM})$ and at day 8 result in $\mathrm{S}>>\mathrm{M}>\mathrm{B}>\mathrm{MM}$. In Figure $2: 2.5$, a, accumulation order $\mathrm{M}>\mathrm{S}>\mathrm{MM}>\mathrm{B}$ at day 2 transforms into $\mathrm{S}>\mathrm{MI}>>\mathrm{MM} \sim \mathrm{B}$ at day 5 .

These results mean that the inversions of accumulation order, i.e. accumulation rate of neutrophils as a whole and their fractions, are frequent. The restoration of the usual neutrophils accumulation order corresponds to the increase of myelocytes content and P/D efficiency index and promotes 


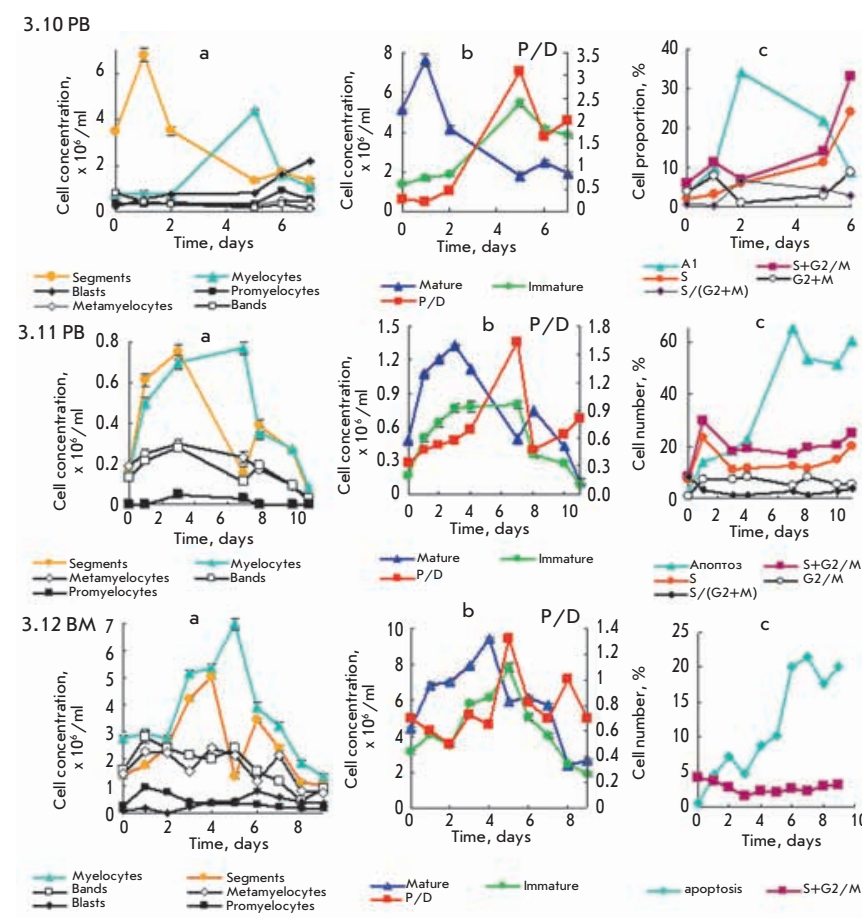

Fig.4. Kinetics plots of proliferation and maturation of subpopulations of $3^{\mathrm{d}}$ type $\mathrm{Ph}^{+}$cells that perform by alternating efficient proliferation and efficient maturation stages according to $2 / 1$ or $2 / 1 / 2$ schemes in the suspension culture of mononuclears from BM or PB of CML patients. Parameters and characteristics of efficient proliferation and efficient maturation of this $\mathrm{Ph}^{+}$cell type, are in table 2 and 3

the transition to effective proliferation. Rate change and inversion of neutrophils accumulation order, synchronous to the decrease of P/D efficiency index (Figs. 1 and 4, d; 2, 3 and $4, \mathrm{~b})$, points to the direct participation of neutrophils in the $\mathrm{P} \& \mathrm{D}$ regulation of $\mathrm{Ph}^{+}$cells types 2 and 3 with inhibition of their proliferation.

Under maturation stage of $\mathrm{Ph}^{+}$cells type 3 with alternation according to schemes $1 / 2,1 / 2 / 1$ in Figure 3 , a the inversion of the accumulation order manifests as transformation from $\mathrm{M}>\mathrm{MM}>\mathrm{S}>\mathrm{B}$ to $\mathrm{M}>\mathrm{S}>\mathrm{MM}>\mathrm{B}$ and then again to $\mathrm{M}>\mathrm{MM}>\mathrm{S} \sim \mathrm{B}$. At alternations according to schemes $2 / 1$ and $2 / 1 / 2$, the inversion of neutrophils accumulation order is seen in Figure 4, a. The neutrophils concentrations are decreasing in row $[\mathrm{S}]>>[\mathrm{M}]>[\mathrm{B}]>[\mathrm{MM}]$, as well as $\mathrm{P} / \mathrm{D}$ index (Fig. 4, b).

Thus, there is inversion of order for consequent neutrophils maturation with their maximum neutrophils accumulation, whose initial order of neutrophils maturation is able to restore by transition to the alternation of the efficient proliferation stage. The extent of this inversion and restoration of the neutrophils accumulation order depends upon the duration of maturation and proliferation stages. Inversion of the accumulation order of M, MM, B, and S is another interesting property of $\mathrm{Ph}+$ cells types 2 and 3 in culture. The rate and extent of neutrophils accumulation is changed: at first it is $\mathrm{S}$; then, B and MM.

Under effective maturation, the neutrophils accumulate in significant quantities due to apoptosis blocking (Fig. 2). They participate in the regulation of $\mathrm{Ph}^{+}$cells types 2 and 3 $\mathrm{P} \& \mathrm{D}$ not only by inhibiting $\mathrm{Ph}^{+}$cells proliferation, but also by inhibiting neutrophils maturation. Inhibition of neutrophils differentiation in $\mathrm{Ph}^{+}$cells types 2 and 3 is revealed at inversion of the initial neutrophils accumulation order with the increase in their concentration (Fig. 2, 3 and Fig. 4, also in Tables 1-3). Inversion of the initial neutrophils accumulation order leads to gradual change of the neutrophils accumulation sequence $\mathrm{M}>\mathrm{MM}>\mathrm{B}>\mathrm{S}$ to $\mathrm{S}>\mathrm{B}>\mathrm{MM}>\mathrm{M}$, and the increase of their concentration in the same order is assumed to proceed by a feedback mechanism. The present inversion of the accumulation order and increase of neutrophils concentration obviously are the result of a stepwise inhibition of the differentiation of every type of neutrophils (by a feedback mechanism) and consequently leads to their accumulation during differentiation of B and MM and, therefore, to inhibition (regulation disturbance) of neutrophils maturation. In other words, $\mathrm{S}$ accumulation inhibits the maturation of $\mathrm{B}$, and it in turn inhibits MM maturation. Finally, all neutrophils maturation orders are inhibited, increasing their concentration. At the same time, neutrophils inhibit $\mathrm{Ph}^{+}$cells proliferation and $P \& D$ efficiency. The next step, after reaching the "critical" neutrophils concentration, is characterized by apoptosis induction. It releases neutrophils from feedback, restores the initial neutrophils accumulation order, after which their concentration decreases, leading to restoration of the regulation of neutrophils accumulation, leading to increase of the $P / D$ efficiency index and transition to effective proliferation of $\mathrm{Ph}^{+}$cells.

The role of proliferation and maturation alternation. The alternation of effective proliferation and maturation with proliferation inhibitions that have different efficiencies and provide rate advantage to either the proliferation or maturation of neutrophils adds periodicity to this process. Efficient proliferation and myelocytes accumulation are synchronous to apoptosis induction, elevation of $\mathrm{P} / \mathrm{D}^{1}>1$, but are asynchronous to neutrophils accumulation, inhibition of proliferation by them, inversion of the neutrophils accumulation order and changes of $\mathrm{P} / \mathrm{D}^{2}$ within $\leq 1$ (Fig. $2-4$, Tables $1-3$ ).

It should be noted that in the regulation of $\mathrm{Ph}^{+}$cells $\mathrm{P} \& \mathrm{D}$, both synchronous and asynchronous processes could be observed. The apoptosis inhibition with neutrophils accumulation without dividing proceeds asynchronous to myelocytes accumulation and apoptosis induction. Myelocytes accumulation is synchronous to apoptosis induction, proliferation activation with increase of $\mathrm{P} / \mathrm{D}$ index, and to restoration of maturation and proliferation regulation.

At the crossing points, $P \& D$ parameters equalize. During types 1 and $2 \mathrm{Ph}^{+}$cells $\mathrm{P} \& \mathrm{D}$, its regulation at a given differentiation cycle becomes "irreversible." Modification of type 3 $\mathrm{Ph}^{+}$cells properties is reversible: during stages alternation the properties inhibited at the previous stage can be restored. By $\mathrm{P} \& \mathrm{D}$ regulation the type $3 \mathrm{Ph}^{+}$cells seems to be more "normal" than type 1 or 2 . All types of $\mathrm{Ph}^{+}$cells probably depend upon the inherited properties of the bcr/abl gene in different CML patients. Of note, the $\mathrm{P} \& \mathrm{D}$ regulation of $\mathrm{Ph}^{+}$cells in all 
three types of $\mathrm{Ph}^{+}$cells from different CML patients differs in the quantitative characteristics of $\mathrm{P} / \mathrm{D}$ efficiency, apoptosis inhibition, $\mathrm{S}$ accumulation, and the extent of $\mathrm{Ph}^{+}$cells proliferation inhibition. Under $\mathrm{P} \& \mathrm{D}$ of $\mathrm{Ph}^{+}$cells types 1 and 2 , its $\mathrm{P} / \mathrm{D}$ efficiency indice varies in the limits $\mathrm{P} / \mathrm{D}^{1}>1$ or $\mathrm{P} / \mathrm{D}^{2}$ $\leq 1$, correspondingly (Fig. 1 and 2, Table 1). It points to some extent of $\mathrm{P} \& \mathrm{D}$ regulation of $\mathrm{Ph}^{+}$cells in limits $\mathrm{P} / \mathrm{D}^{1}>1$ or $\mathrm{P} /$ $\mathrm{D}^{2}$ without changing the initial advantage of the proliferation or maturation rate.

The differences in $\mathrm{P} \& \mathrm{D}$ regulation are related to the properties of $\mathrm{Ph}^{+}$cells from different CML patients at different phases of the disease. Evidently, P\&D efficiency is determined by myeloid cell precursors in $\mathrm{Ph}^{+}$mononuclear cells fraction, inheriting the mutations in bcr/abl gene and p210 tyrosine kinase from different CML patients. The mutations capable of determining carcinogenicity in $\mathrm{Ph}^{+}$cell lines, cell viability, activity of proliferation, and apoptosis blockage are studied in [7, 17, 18, 25, 27, 29, 30].

The alternation of $\mathrm{Ph}^{+}$cells proliferation and maturation ex vivo with the rise or fall of $\mathrm{P} \& \mathrm{D}$ efficiency participates in the regulation and maintenance of an optimum regimen of $\mathrm{Ph}^{+}$ cells $\mathrm{P} \& \mathrm{D}$. Under apoptosis blocking, it alternately switches inhibition of proliferation by maturing neutrophils, especially $\mathrm{S}$, being the progeny of the same proliferating $\mathrm{Ph}^{+}$cells. The cell regulation by segmented neutrophils probably mediates genetic regulation with participation of the bcr/abl gene. These results are concordant with evidence for the separate transforming and antiapoptotic activity of different mutant forms of p210 bcr/abl tyrosine kinase in cell lines that change signal transduction pathways $[8,9,15,17,18,20,27,30,31]$.

As a result, alternation of effective proliferation and effective maturation with the change of increased efficiency indices to very low ones leads to a fall in the overall P\&D efficiency of $\mathrm{Ph}^{+}$cells types 2 and 3 and, thus, maintains a moderate, possibly optimum $P \& D$ regimen. At maturation stages, $\mathrm{P} \& \mathrm{D}$ regulation is mediated by the increase of neutrophils (especially S) content, proliferation inhibition with a decrease of $\mathrm{P} / \mathrm{D}$ efficiency indices, and inversion of the neutrophils maturation order in $\mathrm{Ph}^{+}$cells types 2 and 3 .

\section{DISCUSSION}

The elicited $\mathrm{P} \& \mathrm{D}$ regulation in $\mathrm{Ph}^{+}$cells ex vivo reveals the cellular aspects of genetic $\mathrm{P} \& \mathrm{D}$ regulation. As was shown in the present work, cellular regulation is mediated by alternation of $\mathrm{Ph}^{+}$cells proliferation with efficient maturation and is accomplished by proliferation inhibition by maturating without dividing neutrophils - progenies of the same proliferating $\mathrm{Ph}^{+}$progenitor cells under conditions of apoptosis blockage.

The cellular regulation of hematopoietic cells $\mathrm{P} \& \mathrm{D}$ and its proposed mechanism had previously never been considered in the literature $[4-7,9-12,15,16,21-23,27,30]$. There was no data on the cellular regulation of $\mathrm{Ph}^{+}$cells $\mathrm{P} \& \mathrm{D}$ by mature neutrophils and on the alternation of stages with high and low P\&D efficiency until this study. Also, there was no data on the relative proliferation and maturation rate, their efficiency, and its quantitative equivalent ( $\mathrm{P} / \mathrm{D}$ index). The ratio of proliferating hematopoietic cells and mature neutrophils in single PB samples was designated previously as the maturation index [2].
The proliferation of myeloid progenitor cells and the initial stage of $\mathrm{Ph}^{+}$cells $\mathrm{P} \& \mathrm{D}$ regulation had been extensively studied $[4,5,7,8,10-12,15,16,20,23-25,26]$. It is determined by the proliferative potential and concentration of CD $34^{+}$myeloid progenitor cells. Activation of $\mathrm{Ph}^{+}$cells proliferation depends upon bcr/abl oncogene expression, its mutations, and higher rate of $\mathrm{Ph}^{+}$stem cells transition from $\mathrm{G}_{0}$ to $\mathrm{G}_{1}$ cell cycle phase in comparison with cells without $\mathrm{Ph}$ chromosome [20, 23, 24]. Regulation of $\mathrm{Ph}^{+}$cells proliferation is characterized to some extent (by the kinetic method of P\&D investigation) also in our study. It is clear from the $\mathrm{P} \& \mathrm{D}$ parameters of type $1 \mathrm{Ph}^{+}$ cells and alternations with effective proliferation stages in $\mathrm{Ph}^{+}$cells type 3 . The studies $[33,39]$ have shown the participation of $\mathrm{CD} 34^{+}$myeloid progenitor cells and bcr/abl expression in $\mathrm{Ph}^{+}$cells from $\mathrm{PB}$ sample № 1.1, studied here in $\mathrm{P} \& \mathrm{D}$ regulation of type $1 \mathrm{Ph}^{+}$cells. According to this, a maximum level of CD 34 antigen and bcr/abl expression is coincident with a high, efficient $\mathrm{P} / \mathrm{D}$ index at the beginning of $\mathrm{Ph}^{+}$cells P\&D.

The study [28] on $\mathrm{Ph}^{+}$cells from CML CP patients isolated by flow cytometry has shown a direct relationship between myeloid $\mathrm{Ph}^{+}$progenitors and bcr/abl oncogene expression. The authors have established a decrease in the proliferating $\mathrm{Ph}^{+}$cells fraction in $\mathrm{S}+\mathrm{G} 2 / \mathrm{M}$ phases - by 4 times for myelocytes and by 7 times for B and S in comparison with CD34 ${ }^{+}$ cells. A direct linear correlation of the $\mathrm{Ph}^{+}$cells fraction in $\mathrm{S}+\mathrm{G} 2 / \mathrm{M}$ phases and bcr/abl expression was seen in $\mathrm{CD} 34^{+}$ cells, myeloblasts, and promyelocytes. But later in the course of differentiation, the correlation inverted. It means, that active accumulation of proliferating $\mathrm{Ph}^{+}$cells in $\mathrm{S}+\mathrm{G} 2 / \mathrm{M}$ phases at the beginning of the proliferation stage is proportional to the rise in bcr/abl expression, while during $\mathrm{P} \& \mathrm{D}$ from myelocytes to $\mathbf{B}$ and $\mathbf{S}$ this proportionality inverses. In this study we didn't estimate kinetic parameters. The data used was obtained from a single probe of each of the 15 CML $\mathrm{CP}$ patients. Our results provide a good explanation of this correlation inversion in study [28] by a change in the mechanism of $\mathrm{Ph}^{+}$cells proliferation due to inhibition of $\mathrm{Ph}^{+}$cells proliferation by the neutrophils accumulating under apoptosis blockage.

Taken together, the work of Primo et al [28] and our study indicate the paradoxical mechanism of bcr/abl action on $\mathrm{Ph}^{+}$ cells. The expression of bcr/abl in proliferating myeloid $\mathrm{Ph}^{+}$ progenitors activates proliferation, but later mature $\mathrm{Ph}^{+}$neutrophils that inherit the same oncogene bcr/abl inhibit proliferation. In other words, the promoting proliferation effect of bcr/abl oncogene expression in $\mathrm{Ph}^{+}$cells at early stages of $\mathrm{P} \& \mathrm{D}$ is inhibited by the expression of the same oncogene in the progenies of the same $\mathrm{Ph}^{+}$cells at later stages of maturation. It can be explained, for example, by the change in the signal transduction pathways by bcr/abl oncogene, p210 tyrosine kinase, and spectrum of STAT proteins formed in the neutrophils or in one of them.

Some studies propose an alternative hypothesis on the development and progression of CML, considering the imbalance of stem cells self-renewal and further cell differentiation, rather than the activation of proliferation due to uncontrolled expression of $\mathrm{p} 210^{\mathrm{bcr} / \mathrm{abl}}$, as the main cause of CML $[20-24,13-14,26]$. It is associated with a decreased number of CML progenitor cells, while their progenies in CML are more 
abundant in comparison with that in "normal" cells. Distortion of $\mathrm{Ph}^{+}$cells maturation as a primary biological defect in CML was discussed elsewhere rather long ago [13,14,21, $22,42]$. The example of $\mathrm{Ph}^{+}$cells types 2 and $3 \mathrm{P} \& \mathrm{D}$ in our work shows that such an imbalance is mediated by the neutrophils inhibiting $\mathrm{Ph}^{+}$cells proliferation at maturation stage under apoptosis blockage. The revealed differences in P\&D regulation with inhibition of proliferation by neutrophils with apoptosis blockage and alternation of efficient proliferation and efficient maturation of $\mathrm{Ph}^{+}$cells from different patients inheriting different bcr/abl mutations completely explain the contradictions regarding the imbalance of $\mathrm{Ph}^{+}$cells selfrenewal and maturation.

Proliferation inhibition by neutrophils during the alternation of proliferation and maturation under apoptosis blockage is assumed to regulate also P\&D of hematopoietic cells in normal conditions. In CML, this mechanism can possibly be an attempt by CML cells to escape proliferation activation by bcr/abl expression, leading to CML progression. The threat of CML progression can be seen, for example, at P\&D of type $1 \mathrm{Ph}^{+}$cells under apoptosis induction and absence of neutrophils excess.

\section{CONCLUSIONS}

1. The $\mathrm{P} \& \mathrm{D}$ regulation of $\mathrm{Ph}^{+}$cells from different CML patients is performed by alternation of effective proliferation with effective maturation. In the maturation stage, the $\mathrm{Ph}^{+}$ cells proliferation is inhibited by accumulating neutrophils with apoptosis blockage interrupting proliferation and maintaining the optimum $\mathrm{P} \& \mathrm{D}$ level.

2. The alternation of stages consists in the switching of stage 1 - effective proliferation - when the proliferation rate of $\mathrm{Ph}^{+}$cells exceeds that of maturation, to stage 2 - effective maturation - when apoptosis is blocked, and the neutrophils maturation rate is higher than the proliferation rate. The alternation can proceed according to the schemes $1 / 2-1 / 2 / 1$ or $2 / 1-2 / 1 / 2$. The alternation stages have control points where its plots cross and the indices of proliferation and maturation are equal. The indices of $\mathrm{P} / \mathrm{D}$ efficiency (ratio of proliferation and maturation rates) at control points are equal to $1.06 \pm 0.23$ and don't depend upon time and alternation order, as well as the source of $\mathrm{Ph}^{+}$cells - CML patients. In alternation stages, these indices are permanently changing.

3. In the proliferation stages, the proliferating cells content rises, the number of neutrophils (especially $\mathbf{S}$ ) decreases and apoptosis is activated. In the maturation stages, on the contrary, apoptosis is blocked, the neutrophils content (especially S) is enhanced, while the number of immature is decreased. In the effective maturation stage, accumulating neutrophils inhibit the proliferation of immature $\mathrm{Ph}^{+}$cells and the order (sequence) of neutrophils maturation is inversed and impaired, probably via a feedback mechanism.

4. The differences in $\mathrm{P} \& \mathrm{D}$ regulation allowed us to identify 3 types of $\mathrm{Ph}^{+}$cells in CML patients differing by the number and duration of alternation stages. There are $\mathrm{Ph}^{+}$cells whose $\mathrm{P} \& \mathrm{D}$ has either one prolonged effective proliferation stage or one prolonged effective maturation stage, or multiple alternations of effective stages of proliferation and maturation. The first corresponds to advanced CML phases; the other takes place in the CML chronic phase with good response to chemotherapy.

This work was supported by the Russian Foundation for Basic Research (grant № 06 04-08372-ofi).

\section{REFERENCES}

1. Abdulkadyrov K.M., Bessmeltsev C.C., Rukavitsin O.A. Chronic myelogenous leukaemia.

S-Pb.: Special literature, 1998. 463 pp.

2. Haematological Guideline.- M. Newdiamed, Ed. A.I.Vorobiev. 2002. V.1, 280 pp

3. Blood Patophisiology.- BINOM Publishers, Ed. Ph.D. Shiffman. 2000. 446 pp

4. Deininger M.W.N., Goldman J.M., Melo J.V. // Blood. 2000. V. 96. P. 3343-3356

5. Deininger M.W.N., Vieira S., Mendiola R., et al. // Cancer research. 2000. V. 60. P.2049-2055.

6. Medvedeva N.V. Chronic myelogenous leukaemia.- 50-th annual congress of American

Haematological society. // Clinical oncohaematology, 2009. V. 2. №1. P. 85-88.

7. Melo J.V. // Blood. 1996. V. 88. P. 2375-2384.

8. Holyoake T.L., Jiang X., Eaves A.C., Eaves C.J. // Leukemia. 2002. V. 16. P. 549-558.

9. Holyoake T.L., Jiang X., Jorgensen H.G. et al. // Blood. 2001. V. 97. P. 720-728.

10. Jamieson C.H.M., Ailles L.E., Dylla S.J. et al. // New England J Medicine. 2004. V. 351

P. $657-667$.

11. Jaiswal S., Traver D., Miyamoto T. et al. // Proc.Nat.Acad.. Sci. USA. 2003 V. 100. P. 10002-10007.

12. Passegue E., Jamieson C.H.M., Ailles L. E., Weissman I. L. // Proc.Nat.Acad. Sci. USA. 2003.V. 100. P. $11842-11849$

13. Strife A., Lambek C., Wisniewski D. et al. // Blood. 1983. V. 62. P. 389-397. 14. Strife A., Lambek C., Wisniewski, D. et al. // Cancer Res. 1988. V. 48. P. 1035-1041. 15. Era T., Witte O. N. // Proc. Nat. Acad. Sci. USA. 2000. V. 97. P. 1737-1742. 16. Guzman M.L., Jordan C.T. // Cancer Control. 2004. V. 11, \#(№?)2. P. 97-104. 17. Bedi A., Zehnbauer B.A., Barber J. et al. //Blood. 1994. V. 83. P. 2038-2044. 18. Bedi A., Barber J. P., Bedi G.C et al. // Blood. 1995. V. 86. P. 1148-1158. 19. Brandford S., Rudzki Z., Walsh S. et al. // Blood. 2002. V. 99. P. 3472-3475. 20. Buckle A.M., Mottram R., Pierce A. et al. // Mol. Med. 2000.V. 6. P. 892-902. 21. Clarkson B., Strife A., Perez A. et al. // Leukemia \& Limphoma. 1993. V. 11. P. 81-100 22. Clarkson B., Strife A. // Leukemia. 1993. V. 7. P. 1683-1721.

23. Coppo P., Bonnet M L., Dusanter-Fourt I. et al. // Oncogene. 2003. V. 22(26). P. 4102-4110. 24. Traycoff C.V., Haistead B., Rice S. et al. // Brit. J. Haematology. 1998. V. 102 P.759 - 767

25. Lotem J., Sachs L. // Leukemia. 1996. V. 10. P. 925-9313.

26. Lugo T.G., Pendergast A.M., Muller A.J., Witte O.N. // Science. 1990. V. 247. P. $1079-1082$
27. Cortez D., Kadlec L., Pendergast A.M. // Mol. Cell. Biology. 1995. \#(№?)10. P. $5531-5541$.

28. Primo D., Flores J, Quijano S. et al. // Brit.J. Haematology. 2006. V. 135. P. 43-51. 29. Amarante-Mendes G.P., Naekyung Kim C., Liu L. et al. // Blood. 1998. V. 91. P. $1700-1705$.

30. Selleri C., Maciejewski J.P., Pane F., et al. // Blood. 1998. V. 92. P. 981-989.

31. Sherbenou D.W., Hantschel O., Turaga L. et al. //Leukemia. 2008. V. 22. P. 1184-1190.

32. Stoklosa T., Poplawski T., Koptyra M., et al. // Cancer Res. 2008. V. 68. P. 2576-2580.

33. Akhynina T.V., Gerasimova L.P., Sarkisyan G.P. et al. // Cytology. 2007. V. 49. P. $889-900$.

34. Abramov M.G. Haematological album. M: Medicine, 1985.344 pp.

35. Gerasimova L.P., Manakova T.E., Akhynina T.V. et al. // Russian Journal of Biotherapy. 2002. V.1, № 4. P. 29-38

36. Pinegin B.V., Yiarilin A.A., Simonova A.V. et al. // Apoptosis evaluation of human peripherial blood activated lymphocytes by cytofluorimetric method with propidium jodide // In: Use of flow cytofluorimetry for estimation of human immune system functional activity. M., MH. RF, 2001. P. 48-53

37. Shmarov D.A., Kosinets G.I. Methods of cell cycle analysis by flow cytofluorimetry // In: Laboratorial-clinical meaning of blood analysis by flow cytofluorimetry. M.: Medical Informational Agency, 2004.P. 49-65

38. Dean P.N. // Cell Tissue Kinet. 1980. V. 13. P. 299-302

39. Grineva N.I., Barishnicov A.Ju., Gerasimova L.P. et al. // Russian Journal of Bio-

therapy. 2007. V.6, № 2. P. 21-32

40. Kosinets G.I., Kotelnicov V.M. // Soviet Medicine. 1983. № 4. P. 3-77

41. Kotelnicov V.M., Kosinets G.I., Kasatkina V.V., Kovalevskaya N.P. Kinetics of granulocytepoiesis. // In: Kinetic aspects of haemopoiesis. Tomsk State University. 1982. P. $149-211$

42. Golde D.W., Cline M.J. // New Engl. J. Med. 1973. V. 288. P. 1083-1086.

43. Vladimirskaya E.B. Mechanisms of blood cells apoptosis. // Laboratorial Medicine. 2001. № 4. P. 47-54.

44. Vladimirskaya E.B. Apoptosis and its role in the development of tumor growth. //

In: Biological basis of antitumour therapeutics. M.: Agat-Med, 2001. P. 5-32 45. Dublez L., Eymin B., Sordet O. et al. // Blood. 1998. V. 91. P. 2415-2422. 46. Goldman J. M., Th'ng K.G., Catovsky D., Galton D.A.D. // Blood. 1976. V. 47. P. 381-388. 